\title{
Marine flooding surfaces recorded in Permian black shales and coal deposits of the Main Karoo Basin (South Africa): implications for basin dynamics and cross-basin correlation
}

\author{
Annette E. Götz ${ }^{1,2}$, Katrin Ruckwied ${ }^{3}$, Alexander Wheeler ${ }^{4}$ \\ ${ }^{1}$ University of Portsmouth, School of Earth and Environmental Sciences, Portsmouth, PO1 3QL, \\ United Kingdom \\ ${ }^{2}$ Kazan Federal University, 18 Kremlyovskaya St., Kazan 420008, Republic of Tatarstan, Russian \\ Federation \\ ${ }^{3}$ Shell International Exploration and Production, Houston, TX 77079, USA \\ ${ }^{4}$ The University of Queensland, School of Earth Sciences, St. Lucia, QLD 4072, Australia
}

Corresponding author: Annette E. Götz (annette.goetz@port.ac.uk)

\begin{abstract}
The marine origin of black shales in the context of the Permian postglacial development of the Karoo Basin, South Africa, is subject of an ongoing controversial discussion. Here, we present and discuss palynological and sedimentological data providing evidence of a transgressive event during the early Guadalupian. Palynofacies assemblages of the black shales of the southern basin include marine phytoplankton that exhibit peak abundance within the Whitehill shales and which also occur within siltstones and glauconitic sandstones on top of the No. 5 coal seam of the north-eastern basin. Palynostratigraphic control makes this marine signal a powerful tool for cross-basin correlation. Moreover, palynofacies analysis demonstrates a facies transition from terrestrial lacustrine and fluvio-deltaic in the northeast to deep marine in the south-western parts of the basin.
\end{abstract}

Keywords: Marine-nonmarine correlation; black shales; coal; Permian; Karoo; South Africa. 


\section{Introduction}

Previous works on Permian Karoo black shales provide sedimentological and palaeontological evidence for their marine origin (e.g., Haughton et al., 1953; du Toit, 1954; Rilett, 1963; Hart, 1964, 1969, 1970; Ryan, 1968; McLachlan and Anderson, 1973; Teichert and Rilett, 1974; Stanistreet et al., 1980; Oelofsen, 1987; Visser, 1987, 1989, 1992, 1993, 1994; Visser and Young, 1990; Smith et al., 1993; Johnson et al., 1997, 2006; Scheffler et al., 2006; Buatois et al., 2010; Götz, 2015). Despite this, there is ongoing controversy and discussion concerning the marine or lacustrine origin in the context of the postglacial development of the Karoo Basin (e.g., Cole and McLachlan, 1991; Faure and Cole, 1999; Herbert \& Compton, 2007; Chukwuma and Bordy, 2016; Schulz et al., 2016). This discussion includes the palaeoecology of the famous Permian mesosaurs (Oelofsen, 1981; Oelofsen and Araújo, 1983), interpretations ranging from freshwater, brackish, coastal, lagoonal, hypersaline to normal marine (see Modesto, 2006; Piñeiro et al., 2012; Silva et al., 2017 and references therein). Marine condensed sections have been described from black shales of the Prince Albert and Whitehill formations and interpreted to represent postglacial highstand phases corresponding to coal-forming delta deposits of the north-eastern coalfields (Visser, 1992, 1993, 1995). More recently, a cross-basin correlation of the marine Prince Albert and Whitehill shales and fluvio-lacustrine coal deposits using palynological data was presented by Ruckwied et al. (2014). Glauconitic sandstones, indicative of marine transgressions, are documented from coalfields in the north-eastern part of the basin on top of distinct coal seams (Van Vuuren, 1981, 1983; Cadle, 1982; Cairncross, 1986; Cadle et al., 1993), the most prominent being at the top of the No. 5 coal seam in the Witbank and Highveld coalfields (Hancox and Götz, 2014). From this background and in view of the recent interest in Karoo shales as unconventional gas resource (Decker and Marot, 2012; Mowzer and Adams, 2015), new data from recently drilled deep boreholes in the southern Karoo, as well as published borehole and outcrop data from Karoo black shales and coal deposits are discussed to pinpoint marine transgressions and flooding surfaces on a basin scale. Ultimately, the complexity of basin dynamics within a postglacial setting and related implications for cross-basin correlations are highlighted.

\section{Geological Setting}

The Main Karoo Basin (Fig. 1) comprises a continuous sedimentary succession from the Pennsylvanian to Middle Jurassic known as the Karoo Supergroup (Johnson et al., 2006). It documents the postglacial climate history of central Gondwana marking the transition from the late Palaeozoic Icehouse to the Triassic Hothouse extremes (Montañez et al. 2007; Sun et al., 2012; Scotese, 2016). Depositional environments recorded in the basin fill range from glacio-marine 
(Dwyka Group) to marine-deltaic (Ecca Group), to fluvial (Beaufort Group) and aeolian (Stormberg Group). The lower Ecca Group hosts thick coal-bearing successions in the north-eastern part of the basin and black shales (Ecca shales: Prince Albert, Whitehill, Collingham formations; Johnson, 2009) occur in the central and southern basin. The Karoo succession is capped by $1.4 \mathrm{~km}$ of basaltic lavas of the Drakensberg Group and intruded by mafic dyke swarms (Veevers et al., 1994; Johnson et al., 1996).

The retro-arc foreland basin model for the Main Karoo Basin (Catuneanu et al., 1998) is the most commonly accepted, explaining the partitioning of the basin by flexural tectonics into proximal foredeep, central forebulge, and distal backbulge flexural provinces. More recently, a transtensional foreland system created by subsidence and tilting in a strike-slip regime (Tankard et al., 2009) and a thin-skinned fold belt that developed from collisional tectonics and distant subduction to the south (Lindeque et al., 2011) have been proposed.

Basin-wide correlation is still constrained by the use of mainly nonmarine vertebrates (tetrapods) of low time resolution and the lack of absolute age controls. However, recently published radiometric dates (Fildani et al., 2009; Rubidge et al., 2013; Day et al., 2015; Gastaldo et al., 2015) have improved the existing biostratigraphic correlation scheme. A first basin-wide palynological correlation was recently attempted by Barbolini (2014). Still, the problem of marine-nonmarine correlation can only be solved by precise palynostratigraphic data such as recently obtained from fluvio-lacustrine coal deposits and marine black shales (Ruckwied et al., 2014). Ultimately, a more robust basin-wide correlation scheme will be required for effective exploitation of South Africa's coal and potential shale gas resources (Hancox and Götz, 2014; Götz, 2014, 2015).

\section{Material and Methods}

In 2015, two deep research boreholes (KZF-1, KWV-1), drilled in the southern Karoo Basin (Fig. 1) within the framework of the research programme KARIN (Karoo Research Initiative), intersected Permian black shales of the Prince Albert, Whitehill and Collingham formations (De Kock et al., 2016a, 2016b). Palynological samples from both cores were studied for their sedimentary organic matter content and palynomorph assemblages. Two coal exploration boreholes (BHS14, ALBN11) from the Witbank Coalfield, drilled in 2013, intersected five coal seams developed in the Vryheid Formation (Cairncross, 1986; Hancox and Götz, 2014) and palynological samples were analysed from the No. 2 and No. 5 seams. Previously studied core and outcrop material from black shales in the northern and southern Karoo (Ruckwied et al. 2014; Götz, 2015) and from coal seams of the Witbank and Highveld coalfields in the north-eastern part of the basin (Götz and Ruckwied, 2014; Wheeler 
and Götz, 2016, 2017) are compared with the new data and other available literature data to provide a novel cross-basin correlation scheme for marine and nonmarine deposits based on palynofacies signatures. The KARIN cores are curated at the Council for Geoscience (CGS), Pretoria. Palynological slides are housed at the Geological Museum Kazan Federal University (GM KFU), collection no. 40. Identified palynomorph taxa are listed in Table 1, arranged under probable botanical affinities.

\section{Coal deposits of the north-eastern basin}

The majority of the economically extracted coal in South Africa occurs in the Permian Vryheid Formation (Cairncross, 2001; Hancox and Götz, 2014), which ranges in thickness in the Karoo Basin from less than $70 \mathrm{~m}$ to over $500 \mathrm{~m}$ (Cadle, 1982). Coal seam nomenclature and numbering in the Witbank Coalfield (Fig. 1) distinguishes five to six individual seams (Le Blanc Smith, 1980; Cairncross, 1986; Cairncross and Cadle, 1987, 1988). A palynostratigraphic framework of the coal-bearing succession was provided by Falcon et al. $(1984)$ and later refined by Aitken $(1994,1998)$. The coals show a mean vitrinite reflectance of $0.7 \%$ characteristic of high volatile bituminous coal (Falcon 1986; Falcon and Snyman, 1986; Snyman, 1998; Götz et al., 2012). The palynofacies of the coals are characterized by a high percentage of opaque phytoclasts and distinct pollen and spore assemblages reflecting the change of lowland and upland vegetation in response to postglacial climate amelioration (Falcon et al., 1984; Götz and Ruckwied, 2014; Ruckwied et al., 2014; Wheeler and Götz, 2016, 2017).

In the Witbank Coalfield, the No. 2 coal seam is economically the most important seam containing most of the best quality coal of South Africa (Snyman, 1998). The seam averages $6.5 \mathrm{~m}$ in thickness in the central part of the coalfield, and thins to approximately $3 \mathrm{~m}$ towards the east. In the western sector it may be up to $7 \mathrm{~m}$ thick (Hancox and Götz, 2014). In contrast, seam thickness is more variable in the Highveld Coalfield ranging from $4 \mathrm{~m}$ along the northern margin and up to $10 \mathrm{~m}$ in valleys in the west. The seam thins to less than $1 \mathrm{~m}$ in the east and southeast, and is often not welldeveloped changing to the south into carbonaceous mudstone. In both coalfields the seam splits into a lower (2L) and upper (2U) seam by clastic intra-seam partings (Hancox and Götz, 2014). The palynofacies of the No. 2 coal seam were studied by Götz and Ruckwied (2014), Ruckwied et al. (2014), and Wheeler and Götz $(2016,2017)$ in outcrops and from boreholes, including boreholes ALBN11 and BHS14 discussed below. A prominent change in the composition of palynomorph assemblages records the switch from a fern- and conifer-dominated flora in the lower coal seam to a 
more diverse Glossopteris-Gangamopteris flora in the upper coal seam. This signal is interpreted to indicate the transition from a cold to a fluctuating cool-temperate climate, initiating the switch from icehouse to greenhouse conditions (Falcon et al., 1984; Götz and Ruckwied, 2014; Wheeler and Götz, 2017). A comparable change in floral composition in the adjacent Highveld Coalfield (Wheeler and Götz, 2016), suggests such changes providing a basis for cross-basin correlation (Ruckwied et al., 2014). Palynologically, the No. 2 seam was dated as Artinskian/Kungurian indicating a correlation with black shales of the Prince Albert Formation (Ruckwied et al., 2014). A facies model for the coalbearing environments based on palynofacies is given in Wheeler and Götz (2017), distinguishing between swamp-, lake- and river/delta-controlled sedimentation in a paralic setting and influenced by glacial meltwater input from the hinterlands.

The No. 3 coal seam is poorly developed in the Witbank and Highveld coalfields with thicknesses generally less than $0.5 \mathrm{~m}$ but locally up to $1 \mathrm{~m}$ in the Highveld Coalfield. In borehole BHS14 it has a thickness of $0.4 \mathrm{~m}$ with a thin glauconite-bearing sandy siltstone above the seam. In borehole ALBN11, the seam is not developed. The No. 4 seam is the second most important source of coal in the Witbank Coalfield and varies in thickness from $2.5 \mathrm{~m}$ in the central part of the coalfield to $6.5 \mathrm{~m}$ elsewhere. In places, the seam is divided into a lower (4L) and upper (4U) seam. In the Highveld Coalfield, the No. 4 seam is the major economic seam. The No. $4 \mathrm{~L}$ seam averages $4 \mathrm{~m}$ in thickness, whereas the No. $4 \mathrm{U}$ seam is only of mineable thickness in the western part of the coalfield with an average thickness of $2 \mathrm{~m}$, varying between $1.5 \mathrm{~m}$ and $3.4 \mathrm{~m}$ (Hancox and Götz, 2014). A glauconitic sandstone occurs in the northern part of the coalfield on top of the No. $4 \mathrm{U}$ seam (Winter et al., 1987). In the BHS14 and ALBN11 boreholes, a lower and upper seam is developed. In BHS14 a total thickness of $4.6 \mathrm{~m}$ is encountered, in ALBN11 $3.4 \mathrm{~m}$. In borehole ALBN11, a glauconitic sandstone is developed above the upper seam (4U).

The coal seam No. 5 reaches a thickness between $0.5 \mathrm{~m}$ and $2 \mathrm{~m}$ in the Witbank Coalfield, and in the adjacent southern Highveld Coalfield the thickness ranges between $0.3 \mathrm{~m}$ and $3 \mathrm{~m}$ (Hancox and Götz, 2014). The roof of the seam is formed by a medium- to coarse-grained, laminated glauconitic sandstone (Fig. 2 ) reaching a maximum thickness of up to $1 \mathrm{~m}$ in the western sector of the Witbank Coalfield, informally referred to as the Glauconite Sandstone Marker. It is also well developed in the adjacent southern Highveld Coalfield (Winter et al., 1987) and in the western Vereeniging-Sasolburg and Free State coalfields where it was studied by Hart $(1969,1970)$ who first described marine acritarch assemblages from these glauconitic sandstones. In the central sector of the Witbank Coalfield, the sandstone marker is replaced by siltstones, in places glauconite-bearing. From this part 
of the coalfield, Venter and Cairncross (1995) described marine phytoplankton from a shale horizon near the top of the No. 5 seam.

The here studied boreholes of the central and southern sector reveal a sandy siltstone (BHS14) and organic-rich siltstone (ALBN11) above the seam (Fig. 3). Palynofacies of the seam shows a general high percentage of opaque equidimensional phytoclasts. In borehole ALBN11 a decrease of opaque lath-shaped, and translucent phytoclasts is observed upsection. A similar trend occurs within the group of pollen grains. Spores and amorphous organic matter (AOM) are dominant in the lower seam, and cuticles debris is recorded. Marine acritarchs occur only within the upper part of the seam where opaque equidimensional phytoclasts and degraded organic particles (DOP, mainly degraded translucent phytoclasts) show a prominent increase. The sample from the siltstone above the seam shows the highest proportion of opaque equidimensional phytoclasts, DOP, and marine phytoplankton (acritarchs). In borehole BHS14 opaque equidimensional particles are dominant throughout the seam with exception of a silty horizon in the lower part. Opaque lath-shaped phytoclasts decrease continuously upsection. The same trend is observed within the group of translucent equidimensional plant remains with exception of the sample from the siltstone in the lower seam. Here, also translucent lath-shaped particles show the highest amount. Pollen grains are most abundant in the upper seam, whereas spores show the highest abundances in the lower seam. Freshwater algae (Botryococcus sp., Tetraporina sp.) occur in the silty horizon in the lower seam, whereas marine phytoplankton (acritarchs) were detected in the sandy siltstone above the seam. This sample also shows the highest proportion of DOP and no AOM is preserved. The palynofacies patterns detected in ALBN11 are interpreted to document a shift from swamp to deltaic-marine environments with a clear marine signature on top of the seam marked by maximum abundance of opaque equidimensional particles, DOP and marine acritarchs. In BHS14 a similar shift is observed; however, within the lower seam a lacustrine phase is documented with lowest percentages of opaque equidimensional phytoclasts, highest percentages of translucent particles and the occurrence of freshwater algae. The sandy siltstone above the seam shows a clear marine signature with the highest percentage of opaque equidimensional phytoclasts, DOP, and the occurrence of marine acritarchs. Both boreholes demonstrate that even if a glauconitic sand- or siltstone is not developed, the marine signal on top of the seam can be detected by marine phytoplankton and the change in the composition of sedimentary organic matter. 


\section{Black shales of the central and southern basin}

The Prince Albert Formation overlies the glacio-marine Dwyka tillites with a highly variable thickness of 40 to $150 \mathrm{~m}$ along the western and southern outcrop areas (Johnson et al., 2006) and a maximum thickness of up to $300 \mathrm{~m}$ in boreholes of the SOEKOR exploration drilling programme (Rowsell and de Swardt, 1976). A radiometric date of the base of the Prince Albert Formation ( $288 \pm 3 \mathrm{Ma}$ ) was published by Bangert et al. (1999) from the south-western Karoo Basin. Palynological data suggest an Artinskian-Kungurian age (Ruckwied et al., 2014). Olive grey to dark-grey silty shale with intercalated fine-grained sandstone layers occur in the northern part of the basin, whereas darkgrey, pyrite-bearing shale with chert and phosphatic nodules and lenses occurs in the south (Cole, 2005). Present-day total organic carbon (TOC) values range from less than $1.0 \%$ up to $3.4 \%$ (Aarnes et al., 2011; Geel et al., 2015; De Kock et al., 2017; this study, Tab. 2).

The Whitehill Formation overlies the Prince Albert Formation. Its thickness ranges between 20 and $100 \mathrm{~m}$, thinning from SW to NE (Johnson et al., 2006). It is exposed in outcrops along the basin margin (Chukwuma and Bordy, 2016) and has been identified in the subsurface by numerous boreholes of the SOEKOR exploration drilling programme (Rowsell and de Swardt, 1976) and recent research boreholes of the KARIN research programme (De Kock et al. 2016a, 2016b), where it ranges in depth from 450 to 3000 m below surface. Radiometric dates are not yet available for the Whitehill Formation in South Africa. However, palynological data suggest a Roadian age (Ruckwied et al., 2014). In outcrops, the white-weathering shale is distinguished from the dark to olive grey lithologies of the under- and overlying Prince Albert and Collingham/Tierberg formations (Cole and Basson, 1991). Lateral facies changes enable to distinguish a northern shallow and southern deeper depositional environment (Chukwuma and Bordy, 2016). Present-day total organic carbon (TOC) values range from less than 1.0\% up to $18.5 \%$ (Oelofsen, 1987; Cole and McLachlan, 1991; Aarnes et al., 2011; Geel et al., 2013, 2015; Smithard et al., 2015; De Kock et al., 2016b, 2017; this study, Tab. 2).

The Collingham Formation overlies the Whitehill Formation in the southern and western parts of the basin and is the stratigraphic equivalent of the Tierberg Formation developed in the north-western Karoo Basin (Cole and Basson, 1991). The formation is between 30 and $70 \mathrm{~m}$ thick (Viljoen, 1992) and comprises a rhythmic alternation of thin, dark-grey shales and very thin tuff layers (Johnson et al., 2006). The tuff layers are considered to be silicic air-fall tuffs which underwent secondary alteration to K-bentonites (Viljoen, 1992). Recently published U-Pb zircon ages from the Ecca Pass section (McKay et al., 2015) place the base of the formation chronostratigraphically in the early Guadalupian. Palynological data from the Ecca Pass suggest a Roadian age (Götz, 2015) consistent with the radiometric dates of McKay et al. (2015). Present-day total organic carbon (TOC) values 
range from less than 1.0\% up to 2.8\% (Geel et al., 2015; De Kock et al., 2017; this study, Tab. 2). Values from the Tierberg Formation of the northern Karoo Basin are below 1.0\% (Aarnes et al., 2011).

Palynofacies assemblages of the studied black shales (Fig. 4) reveal a high percentage of phytoclasts in all parts of the basin, whereas the proportions of amorphous organic matter (AOM), sporomorphs and marine phytoplankton (acritarchs, prasinophytes) are more variable, stratigraphically and laterally. In the northern part of the basin (DP 1/78), the sedimentary organic matter of the Whitehill shales reveals a shallow marine, restricted setting with low marine phytoplankton percentages (leiospheres, prasinophytes), low AOM preservation, high phytoclast input, and a high spores:bisaccates ratio, data plotting in field II of the AOM-Phytoclast-Palynomorph ternary diagram (Fig. 4a). In the south-eastern part (KWV-1), palynofacies suggests a stratified deep basin setting with low marine phytoplankton percentages (prasinophytes), good AOM preservation, high terrestrial input, and a moderate spores:bisaccates ratio, data plotting in field IVa (Fig. 4a). Further to the south (Ecca Pass), the percentage of AOM increases, data plotting in field IVb. In the southwestern basin (KZF-1), the palynofacies indicates a distal marine basinal setting with moderate marine phytoplankton percentages (acritarchs, prasinophytes), good AOM preservation, low terrestrial input, and low spores:bisaccates ratios, data plotting in field VII (Fig. 4a). The highest percentage of marine phytoplankton was detected in the middle Whitehill Formation (Fig. 5), most prominent in the south-eastern and northern sections (KWV-1, DP 1/78).

The underlying Prince Albert shales of the northern basin (DP 1/78) are characterized by a high proportion of phytoclasts, translucent particles prevalent, and bisaccate pollen grains, with very low AOM and marine phytoplankton preservation and data plotting in field II of the AOM-PhytoclastPalynomorph ternary diagram (Fig. 4a). A shallow marginal marine, less-restricted setting is inferred for the Whitehill shales. In the south-eastern part (KWV-1), palynofacies points to a basinal setting with moderate marine plankton percentages (acritarchs), low AOM preservation, and a high proportion of opaque equidimensional phytoclasts, data plotting in field II (Fig. 4a). In the south (Ecca Pass), similar palynofacies are present with low AOM preservation and abundant opaque phytoclasts, data plotting in field II (Fig. 4a). In the south-western basin (KZF-1), palynofacies reveals a stratified deep basin setting with low marine phytoplankton percentages (prasinophytes), good AOM preservation, high terrestrial input, and a moderate spores:bisaccates ratio, data plotting in field IVa (Fig. 4a).

The overlying basal Collingham shales studied in the southern basin (KZF-1, Ecca Pass) reveal a high content of both AOM and prasinophytes, characteristic of a deep, stratified marine basin, data 
plotting in field IVb (Fig. 4b). Upsection, a marked shallowing is documented in both areas with palynofacies characterized by a high input of phytoclasts and a high spores:bisaccates ratio, data plotting in fields IVa and III (Fig. 4b). In the northern basin (DP 1/78) palynofacies is dominated by woody debris and reveals a high spores:bisaccates ratio, data plotting in field III (Fig. 4b).

Some authors consider prasinophytes to be an indicator of cold reduced salinity waters (e.g., Leckie et al., 1992). In this case, a change from a predominance of acritarchs to one of prasinophytes could be construed as a signal of decreased salinity. On the other hand, prasinophytes may be associated with stratification rather than salinity per se, and thus may increase distally for this reason, as documented in numerous studies on black shales of Palaeo- and Mesozoic basins (e.g., Tyson, 1987, 1995; Gorin and Feist-Burkhardt, 1990; Prauss et al., 1991; Lüning et al., 2000). In this context it is also worth mentioning that Permian low-diversity organic-walled microplankton assemblages (Fensome et al., 1990; Strother, 1996; Traverse, 2007; Lei et al., 2013) might complicate the identification of variations in marine influence. Thus, palynofacies analysis, the study of all sedimentary organic particles, their changes in composition, size spectra and preservation states (cf. Combaz, 1964, 1980; Tyson, 1993, 1995) - stratigraphically and laterally - as applied here to Karoo shales and coals is seen as a very powerful tool to detect such variations and different depositional environments in the context of the postglacial basin evolution.

\section{Correlation}

Palynostratigraphy allows for correlation of coal deposits and black shales on a basin scale (Fig. 6). Palynomorph assemblages of the No. 2 and No. 5 coal seams were identified also in marine black shales (Ruckwied et al., 2014; Götz and Wheeler, 2017). The lower part of the No. 2 coal seam (lower seam 2L) is dominated by Cannanoropollis spp. (= Virkkipollenites), Potonieisporites spp. and Plicatipollenites sp., and horsetail and fern spores such as Calamospora spp., Microbaculispora spp., Punctatisporites spp., and Verrucosisporites spp. The presence of Florinites spp. places this assemblage into the Virkkipollenites-Plicatipollenites-Potonieisporites-Florinites sub-assemblage, i.e. Biozone Ic of Falcon et al. (1984), revealing an Artinskian-Kungurian age (Ruckwied et al., 2014). The assemblage of the upper seam (2U) is dominated by Sulcatisporites spp., Protohaploxypinus spp., and Alisporites spp. and placed into the Sulcatisporites-Virkkipollenites-PlicatipollenitesPotonieisporites sub-assemblage, i.e. Biozone lld of Falcon et al. (1984). The presence of key marker species Protohaploxypinus limpidus implies a placement within the Vittatina costabilis Interval Zone of Souza and Marques-Toigo (2005). As identified for the Whitehill shales, a high percentage of 
Vittatina spp., a general increase of the striate bisaccate pollen group, and the consistent presence of Guttulapollenites hannonicus and Lueckisporites virkkiae is characteristic of the No. 5 coal seam (Ruckwied et al., 2014; Götz and Wheeler, 2017). Thus, the upper Prince Albert Formation and Whitehill Formation are interpreted to belong to the Lueckisporites virkkiae Interval Zone regarded as late Cisuralian (Kungurian) to early Guadalupian (Roadian) (Souza and Marques-Toigo, 2005), whereas the lower Prince Albert Formation still belongs to the early Cisuralian (Artinskian) Vittatina costabilis Interval Zone (Ruckwied et al., 2014; Götz and Wheeler, 2017). The basal Collingham Formation is dominated by Lueckisporites spp., Vittatina spp., and Weylandites lucifer (Götz, 2015; Götz and Wheeler, 2017), placing this part of the formation into the Lueckisporites virkkiae Interval Zone of Souza and Marques-Toigo (2005). U-Pb zircon ages from the base of the Collingham Formation (268 \pm 3.2 Ma; McKay et al., 2015) are in agreement with the palynostratigraphic dates, indicating an early Guadalupian (Roadian) age.

Barbolini (2014) noted the shared taxa between South Africa and Australia, but found challenges in correlation based on endemism and palaeoenvironmental differences. This was explored further in Barbolini et al. (2016), which provides a detailed analysis of potential diachroneity between the pollen assemblages of South Africa and Australia. The comparison of both the palynological record and radiometric dates from both countries highlights the difficulties in large-scale regional correlations using the same index taxa. Furthermore, the limited number of radiometric dates in early Permian (Cisuralian) sections compared to late Permian (Lopingian) sections in both countries is problematic as entire formations are constrained by only one or two dates.

In terms of palynological correlation on an intrabasinal scale, there are also constraints within the Karoo Basin, especially in the Cisuralian. The scheme developed by Anderson (1977) places the No. 5 coal seam into the $3 b / 3 c$ biozones. Falcon $(1975,1978)$ developed a zonation based on reference sections in Zimbabwe, and placed the No. 5 coal seam into zone IVg. Aitken (1994), however, suggests a younger age of zone IVh' attributing the different age placements to local environmental variation. This study also suggests that the No. 5 coal seam can be assigned to Biozone $F$ using the scheme of MacRae (1988), which was developed based on samples from the Waterberg and Pafuri sub-basins of the northern Karoo. Aitken (1998) indicates the Whitehill Formation tentatively correlates with the Volksrust Formation based on the assignment of Biozone VI, while the No. 5 coal seam is assigned to the older Biozone V. Barbolini (2014) correlates the Whitehill Formation in the southern part of the basin with the Pietermaritzburg Formation in the northern part by identifying taxa with restricted ranges which may be useful for correlation. This study does note that many of 
these taxa are restricted to specific facies in certain parts of the basin and thus cannot be used to directly correlate to a different part of the basin within the same lithostratigraphic horizon.

Ultimately, a scheme based on the first appearance of specific index taxa similar to the scheme of sections calibrated by radiometric age dates used in Australia (Price, 1997; Laurie et al., 2016) would potentially be extremely useful in developing more accurate intrabasinal correlations in the Main Karoo Basin. However, abundant ashfall tuff marker beds spanning the Sydney, Gunnedah and Bowen basins allow for verification of absolute ages over large distances (Metcalfe et al., 2015; Nicoll et al., 2015; Ayaz et al., 2016; Laurie et al., 2016). This is a more difficult task in the Main Karoo Basin as the ashfall tuff deposits are limited to the southern part of the basin. Thus, future work dating the glauconitic sandstones associated with the coals in the north may offer a solution, but in the interim we propose a correlation based on basin-scale palaeoenvironmental events displayed in distinct palynofacies patterns.

Palynofacies reveals changes in the composition of sedimentary organic matter reflecting different depositional environments (Fig. 7). Within coal seams the change from swamp, lake, river and deltaic to shallow marine environments is documented in stratigraphic and lateral changes of organic particles. The No. 5 coal seam documents a major marine transgression with marine phytoplankton occurrence. In contemporaneous marine black shales of the Whitehill Formation different basinal environments ranging from marginal restricted, shallow to deep marine, with partly stratified water bodies are well recorded in the palynofacies (Fig. 4). The highest variability of phytoclast size and shape is documented in the northern basin (DP 1/78), characteristic of proximal settings (Tyson, 1995). The acritarch peak detected within the Whitehill shales corresponding with the occurrence of marine plankton in siltstones and glauconitic sandstones on top of the No. 5 coal seam is interpreted to indicate a maximum flooding zone. Lower in stratigraphy, glauconitic siltstones and sandstones were detected on top of the No. 3 coal seam (Free State and Vereeniging-Sasolburg coalfields; e.g., Hart 1969; Anderson, 1977; Stavrakis, 1986; Steyn and Van der Linde, 1986) and above the No. 4 coal seam (Witbank and Highveld coalfields; e.g., Le Blanc Smith, 1980; Cadle, 1982; Winter, 1985; Winter et al., 1987), probably also representing flooding intervals. Anderson (1977) described the acritarch species Micrhystridium karooense from a glauconitic siltstone on top of the No. 3 coal seam intersected in a borehole south of Sasolburg (Vereeniging-Sasolburg Coalfield). Le Blanc Smith (1980) interpreted the Witbank coals as fluvio-deltaic deposits with periods of peat accumulation invariably terminated by transgression and swamp drowning. Hart $(1969,1970)$ identified three marine horizons within the coal-bearing Vryheid Formation on top of the No. 2, 3 and 4 coal seams and Cairncross and Cadle (1988) described a marine transgressive sequence above the No. 2 coal seam. 
The higher percentages of marine acritarchs, compared to our findings from the Witbank Coalfield, reported by Hart (1969) and Anderson (1977) from boreholes of the northern Free State province reflect the proximal-distal positon within the basin, the Witbank coal-bearing facies representing the most proximal setting.

Gondwanan postglacial transgressive events have been recognized as a result of the combined effect of fast glacioeustatic sea-level rise and subsidence along basin margins (López-Gamundí, 2010) and landward marine pulses as reflected in the proximal coal series of the north-eastern Karoo Basin are to be expected. In a sequence stratigraphic context, the Karoo coal seams are thus interpreted as transgressive seams (cf. Diessel, 1992, 1998) formed when creation of accommodation was large (Gastaldo et al., 1993; Aitken and Flint, 1995; Bohacs and Suter, 1997). A similar pattern of multiple transgressive pulses with maximum flooding occurring above coal seams was recognized by Holz $(1998,1999)$ in early Permian coal deposits of the Paraná Basin and it was demonstrated that variations in the palynological record are related to changes in relative sea level (Holz and Dias, 1998). By contrast, Catuneanu et al. (2002) place the maximum flooding surface within the coal seams on top of laminated siltstones and interpret the Karoo coals to have developed at the maximum regressive surface. The five detected T-R sequences are divided into transgressive systems tracts related to marine flooding of the forebulge area (Catuneanu et al., 1998) and regressive systems tracts reflecting regressions of the distal Ecca shoreline in relation to fluvial-deltaic progradation. With regard to the postulated basin partitioning by flexural tectonics into proximal foredeep, central forebulge, and distal backbulge areas (Catuneanu et al., 1998), the regressive character of the coals seems reasonable. However, compilation of new palynological and sedimentological data presented here, and data available from previous studies on Karoo coals, and comparison with similar settings in South America (Holz, 1999), leads to a different interpretation of the basin architecture and development of accommodation space. From the palynofacies patterns detected in the sections studied from different basin areas, a basin architecture from NE to SW with terrestrial lacustrine, fluvio-deltaic, and shallow to deep marine environments is inferred (Figs. 7, 8). Based on palynostratigraphy, marine black shales of the Prince Albert and Whitehill formations are interpreted as stratigraphic equivalents of the terrestrial coal deposits of the Vryheid Formation (Ruckwied et al., 2014). Facies changes within the Whitehill Formation described by Chukwuma and Bordy (2016) indicate also a deepening from the northern towards the southern parts of the basin. The model of a transtensional foreland system created by subsidence and tilting in a strike-slip regime (Tankard et al., 2009) might thus better account for the observed marine pulses and different depositional environments related to the NE-SW deepening basin architecture than partitioning of 
the basin by flexural tectonics as envisioned in the retro-arc foreland basin model by Catuneanu et al. (1998). As discussed in Tankard et al. (2009), the basin evolution is strongly related to the Archean and Proterozoic basement blocks underlying the Karoo. The development of an early/mid Permian southward-deepening ramp syncline related to lithospheric subsidence facilitated by crustal-scale faults, led to stratigraphic northeastwards thinning of the Prince Albert and Whitehill formations above subsiding Namaqua basement onto the elevated Kaapvaal craton, and merging with the coal-bearing Vryheid Formation. Deeper facies above the southern Namaqua and eastern Natal basement blocks and stratigraphic thinning and deposition in marginal and non-marine settings on Kaapvaal basement in the north occurs during late Cisuralian (early/mid Ecca) times, while Guadalupian/Lopingian (late Ecca/Beaufort) times are characterized by pronounced tectonic unloading and uplift in the southern Karoo and subsidence in the northeast. Indeed, palynofacies data so far available for different parts of the basin point to a much more complex basin architecture with partly - regionally and temporally - restricted and stratified areas (Fig. 8). Thus, a transtensional system with spatiotemporal development of areas of different subsidence rates and accommodation space probably accounts best for the detected facies patterns.

As described from the Paraná Basin (Holz et al., 2002), the Karoo coals also appear to have developed during transgressive phases with maximum flooding occurring above the distinct seams. The most prominent marine signature above the No. 5 coal seam might reflect the superposition of maximum flooding zones of 3rd and 2nd order sequences (Roadian ("upper Ecca") 3rd order Sequence/"Ecca-Beaufort" 2nd order Sequence, corresponding to the "Gondwana I" Sequence of the Paraná Basin; see Milani et al., 1994, 1998; lannuzzi et al., 2010), and the less pronounced signals above the seams No. 2, 3 and 4 might represent 3rd order signatures (Artinskian and Kungurian ("lower-middle Ecca") sequences). As the marine event above the No. 5 seam is correlatable with a major basinal marine pulse within the Whitehill Formation, representing "transgressive" black shales (Wignall, 1994), it serves as a cross-basin correlation marker horizon. In a global context, the here detected basin-wide marine signature might record the early Guadalupian (Roadian) initial transgression (Henderson et al., 2012). Interestingly, the Roadian transgression seems to be related to a global $\mathrm{CO}_{2}$ greenhouse crisis (Retallack, 2011, 2013), marking a phase of drastic climate change. With regard to the recent demand for establishing global marine-nonmarine correlation schemes for the Permian as outlined by Shen et al. (2013) and Schneider et al. (2014), the "Whitehill event" is thus a suitable candidate for improvement of the Karoo stratigraphy. 
In contrast to the continuous marine depositional environment for the Prince Albert, Whitehill and basal Collingham formations and major flooding phases recorded in contemporaneous coal deposits favoured here, Schulz et al. (2016) proposed a basin model that includes stratified water bodies comprising anoxic bottom waters overlain by less dense sub-saline waters with high bioproductivity. The authors argue that this analogue to the present-day Baltic Sea describes best the preservation of organic matter with regard to geochemical and mineralogical signals indicating fresh water influence (e.g., Herbert and Compton, 2007). Undoubtedly, there must have been freshwater introduced into the basin associated with the fluvio-deltaic coal-bearing facies of the north-eastern part of the basin. Whether this was sufficient to produce a marked salinity stratification of the whole basin for all or some of the Roadian (Whitehill) time is unclear, but evidently it was insufficient to prevent the observed acritarch signal in the southern part of the basin. If the surface salinity was depressed, any marine influence would be most marked in the bottom water and weakest in the surface waters. A sufficiently freshened surface water would inhibit marine phytoplankton (especially diversity) while sub-halocline faunas would probably be inhibited by dysoxia-anoxia even if not the salinity. On the other hand, following the Baltic model, a marine basin where enhanced meltwater runoff occurs during deglaciation produces a strong salinity stratification. Consequently, a change from the deposition of the Prince Albert to the Whitehill shales would be expected with the marine signal in proximal areas representing times of reduced runoff. This in turn would argue for deglaciation meltwater episodes rather than steady deglaciation rates. However, the meltwater peak after the Dwyka glaciation would be expected much earlier during Artinskian-Kungurian (Prince Albert) times. Considering the Weichselian deglaciation model proposed by Haldorsen et al. (2001) for the early Permian Karoo Basin, deglaciation was completed within thousands rather than millions of years and would have hardly affected the depositional environments of the Prince Albert and Whitehill formations. Sulphur values of Whitehill shales (2-8 wt.\%; Geel et al., 2013; Costin and Götz, 2017 ) are similar to those reported from the non-lacustrine intervals of deep anoxic basins of the Baltic Sea (e.g., Sternbeck and Sohlenius, 1997; Böttcher and Lepland, 2000), indicating marine bottom water inflows that supply sufficient sulphate for sulphate reduction in the deep-water sediments and thus leading to elevated pyrite and sulphur content. It is the saline bottom water inflows that cause the current strong permanent stratification of the Baltic deeps, so the addition of marine influence, rather than just deglaciation, also plays a part in the Baltic model.

The transgression model postulates a marine basin with relatively localised freshwater input only. The transgressive pulse resulted in the change to marine black shales distally and correlative supracoal acritarch horizons proximally. Such a correlation would apparently preclude a high runoff salinity stratification mechanism for the Whitehill Formation, although the surface salinity was not 
necessarily fully marine even during the transgressive maximum. Still, the marine basin became anoxic in the south at the marine maximum, which might have been partly a function of depth. Then again, if both shallow surface waters (in the north-eastern part of the basin) and deep water (in the southern part of the basin) were both marine, before and after the marine peak, increased runoff would have been responsible for the stratification that produces the black shale basin. Hence, the coincidence of the final deglaciation episode with a major transgressive pulse during the Roadian greenhouse crisis of significant warming (Retallack, 2013) is interpreted to have controlled black shale deposition in the deeper basin causing the Whitehill event.

Additionally, trace fossils also indicate marine environments for the Ecca shales with a depauperate Cruziana and Glossifungites ichnofacies described from the western and southern Karoo Basin (Buatois et al., 2010). Thus, the transgression model presented herein, with its distinct basin-wide flooding phases seems to be more plausible than a water stratification model due to melt water. Still, a lot of questions remain including cyclic climatic variations in runoff, variations in salinity, and frequency of flooding events.

Ultimately, a high-resolution palynofacies analysis of the Karoo shales can in the future contribute to answer these questions which will further stimulate the discussion whether continuous marine conditions characterize black shale deposition during late Cisuralian/early Guadalupian (Ecca) times or whether melt water influx controlled ocean circulation and black shale deposition. So far, no freshwater algae were detected to support freshwater conditions from a palynological point of view. Also geochemical proxies, in particular $\mathrm{Rb} / \mathrm{K}$ and $\mathrm{V} / \mathrm{Cr}$ ratios indicate constant marine conditions during the deposition of the Prince Albert Formation and the development of anoxic bottom water conditions in a deep water environment (Scheffler et al., 2006). The data set presented by Scheffler et al. (2006) furthermore shows that marine conditions and anoxic bottom water persisted during deposition of the Whitehill and until the lower Collingham formations.

\section{Conclusions}

A major transgression event during the early Guadalupian (Roadian) recorded in black shales and coal deposits of the Karoo Basin is proposed for cross-basin correlation based on palynostratigraphy and palynofacies analysis. Palynofacies furthermore reveals changes in the composition of sedimentary organic matter reflecting a basin architecture related to a transtensional foreland system with spatiotemporal development of areas of different subsidence rates and accommodation space. From the palynological record, continuous marine conditions characterize black shale deposition during the late Cisuralian/early Guadalupian. However, in the future the study of a 
proximal-distal transect of wells across the Karoo, allowing for more detailed integrated palynological, geochemical and sedimentological data analysis, is needed to unravel the complex postglacial basin and climate history of the Main Karoo Basin.

\section{Acknowledgements}

This study is part of the research conducted within the framework of the Karoo Research Initiative (KARIN) under the umbrella of the NRF-DST Centre of Excellence for Integrated Mineral and Energy Resource Analysis (CIMERA) hosted by the University of Johannesburg and co-hosted by the University of the Witwatersrand. Discussions with George Hart, a pioneer in Karoo palynology, encouraged us to dive into the marine-nonmarine discussion from a palynological perspective. The thorough review by Richard Tyson and comments by two anonymous reviewers are gratefully acknowledged.

\section{References}

Aarnes, I., Svensen, H., Polteau, S., Planke, S., 2011. Contact metamorphic devolatilization of shales in the Karoo Basin, South Africa, and the effects of multiple sill intrusions. Chemical Geology 281(34), 181-194.

Aitken, G., 1994. Permian palynomorphs from the Number 5 Seam, Ecca Group, Witbank/Highveld Coalfields, South Africa. Palaeontologia africana 31, 97-109.

Aitken, G.R., 1998. A Palynological and Palaeoenvironmental Analysis of Permian and Early Triassic Sediments of the Ecca and Beaufort Groups, Northern Karoo Basin, South Africa. Unpublished PhD Thesis, University of the Witwatersrand, Johannesburg, 499 pp.

Aitken, J.F., Flint, S.S., 1995. The application of high-resolution sequence stratigraphy to fluvial systems: a case study from the Upper Carboniferous Breathitt Group, eastern Kentucky, USA. Sedimentology 42, 3-30. 
Anderson, J.M., 1977. The biostratigraphy of the Permian and Triassic. Part 3. A review of Gondwana palynology with particular reference to the northern Karoo Basin. Memoirs of the Botanical Survey of South Africa 41, 1-67.

Ayaz, S.A., Martin, M., Esterle, J., Amelin, Y., Nicoll, R.S., 2016. Age of the Yarrabee and accessory tuffs: implications for the upper Permian sediment-accumulation rates across the Bowen Basin. Australian Journal of Earth Sciences 63(7), 843-856.

Balme, B.E., 1995. Fossil in situ spores and pollen grains: An annotated catalogue. Review of Palaeobotany and Palynology 87, 81-323.

Bangert, B., Stollhofen, H., Lorenz, V., Armstrong, R., 1999. The geochronology and significance of ash-fall tuffs in the glaciogenic Carboniferous-Permian Dwyka Group of Namibia and South Africa. Journal of African Earth Sciences 29, 33-49.

Barbolini, N., 2014. Palynostratigraphy of the South African Karoo Supergroup and correlations with coeval Gondwanan successions. PhD Thesis, University of the Witwatersrand, Johannesburg, 386 pp.

Barbolini, N., Bamford, M.K., Rubidge, B., 2016. Radiometric dating demonstrates that Permian spore-pollen zones of Australia and South Africa are diachronous. Gondwana Research 37, 241-251.

Bohacs, K., Suter, J., 1997. Sequence stratigraphic distribution of coaly rocks: fundamental controls and paralic examples. AAPG Bulletin 81, 1612-1639.

Böttcher, M.E., Lepland, A., 2000. Biogeochemistry of sulfur in a sediment core from the westcentral Baltic Sea: evidence from stable isotopes and pyrite textures. Journal of Marine Systems 25(3-4), 299-312.

Buatois, L.A., Netto, R.G., Mángano, M.G., 2010. Ichnology of late Paleozoic postglacial transgressive deposits in Gondwana: Reconstructing salinity conditions in coastal ecosystems affected by strong meltwater discharge. In: López-Gamundí, O.R., Buatois, L.A. (Eds.), Late Paleozoic Glacial Events and Postglacial Transgressions in Gondwana. GSA Special Paper 468, 149-173. 
Cadle, A.B., 1982. Controls on coal distribution. In: Cadle, A.B. (Ed.), Coal Exploration, Economics and Assessment. University of the Witwatersrand, Johannesburg, p. 36.

Cadle, A.B., Cairncross, B., Christie, A.D.M., Roberts, D.L., 1993. The Karoo Basin of South Africa: Type basin for the coal-bearing deposits of southern Africa. International Journal of Coal Geology 23, 117-157.

Cairncross, B., 1986. Depositional Environments of the Permian Vryheid Formation in the East Witbank Coalfield, South Africa: A Framework for Coal Seam Stratigraphy, Occurrence and Distribution. PhD Thesis, University of the Witwatersrand, Johannesburg, 232 pp.

Cairncross, B., 2001. An overview of the Permian (Karoo) coal deposits of southern Africa. Journal of African Earth Sciences 33, 529-562.

Cairncross, B., Cadle, A.B., 1987. A genetic stratigraphy for the Permian coal-bearing Vryheid formation in the east Witbank Coalfield, South Africa. South African Journal of Geology 90(3), 219230.

Cairncross, B., Cadle, A.B., 1988. Depositional palaeoenvironments of the coal-bearing Vryheid formation in the east Witbank Coalfield, South Africa. South African Journal of Geology 91(1), 1-17.

Catuneanu, O., Hancox, P.J., Rubidge, B.S., 1998. Reciprocal flexural behaviour and constrasting stratigraphies: a new basin development model for the Karoo retroarc foreland system, South Africa. Basin Research 10, 417-439.

Catuneanu, O., Hancox, P.J., Cairncross, B., Rubidge, B.S., 2002. Foredeep submarine fans and forebulge deltas: orogenic off-loading in the underfilled Karoo Basin. Journal of African Earth Sciences 35, 489-502.

Chukwuma, K., Bordy, E.M., 2016. Spatiotemporal sedimentary facies variations in the Lower Permian Whitehill Formation, Ecca Group, Karoo Basin. In: Linol, B., de Wit, M.J. (Eds.), Origin and Evolution of the Cape Mountains and Karoo Basin. Regional Geology Reviews, Springer, pp. 101-110. 
Cole, D.I., 2005. Prince Albert Formation. In: Johnson, M.R. (Ed.), Catalogue of South African lithostratigraphic units. South African Committee for Stratigraphy, Pretoria, pp. 33-36.

Cole, D.I., Basson, W.A., 1991. Whitehill Formation. In: Johnson, M.R. (Ed.), Catalogue of South African lithostratigraphic units. South African Committee for Stratigraphy, Pretoria, pp. 51-52.

Cole, D.I., McLachlan, I.R., 1991. Oil potential of the Permian Whitehill Shale Formation in the main Karoo Basin, South Africa. In: Ulbrich, H., Rocha Campos, A.C. (Eds.), Gondwana Seven Proceedings. Instituto de Geociências, Universidade de Sao Paulo, Sao Paulo, Brazil, pp. 379-390.

Combaz, A. 1964. Les palynofaciès. Revue de Micropaléontologie 7, 205-218.

Combaz, A. 1980. Les kérogènes vus au microscope. In: Durand, B. (Ed.), Kerogen: Insoluble Organic Matter From Sedimentary Rocks. Editions Technip, Paris, pp. 55-111.

Costin, G., Götz, A.E., 2017. Application of FE-EPMA to sedimentary organic matter characterization of Permian Karoo black shales. Abstract volume, The Golden Anniversary Meeting of AASP - The Palynological Society, Nottingham, UK, p. 71.

Day, M.O., Ramezani, J., Bowring, S.A., Sadler, P.M., Erwin, D.H., Abdala, F., Rubidge, B.S., 2015. When and how did the terrestrial mid-Permian mass extinction occur? Evidence from the tetrapod record of the Karoo Basin, South Africa. Proceedings of the Royal Society B 2015282 20150834; DOI: 10.1098/rspb.2015.0834.

Decker, J., Marot, J., 2012. Investigation of hydraulic fracturing in the Karoo of South Africa. Annexure A, Resource Assessment, Petroleum Agency SA. Available at: http://www.dmr.gov.za/ publications/viewdownload/182/854.html

De Kock, M.O., Beukes, N.J., Götz, A.E., Cole, D., Robey, K., Birch, A., Withers, A., van Niekerk, H.S., 2016a. Progress report on exploration of the southern Karoo Basin through CIMERA-KARIN borehole KZF-1 in the Tankwa Karoo, Witzenberg (Ceres) district. CIMERA-KARIN Open-File Report 2016-1, Johannesburg, $12 \mathrm{pp}$. 
De Kock, M.O., Beukes, N.J., van Niekerk, H.S., Cole, D., Robey, K., Birch, A., Götz, A.E., 2016b. Progress report on investigation of the southeastern Main Karoo Basin through CIMERA-KARIN borehole KWV-1 near Willowvale in the Eastern Cape Province. CIMERA-KARIN Open-File Report 2016-2, Johannesburg, 13 pp.

De Kock, M.O., Beukes, N.J., Adeniyi, E.O., Cole, D., Götz, A.E., Geel, C., Ossa, F.-G., 2017. Deflating the shale gas potential of South Africa's Main Karoo Basin. South African Journal of Science 113(9/10), Art. \#2016-0331, 12 pp.

Diessel, C.F.K., 1992. Coal-Bearing Depositional Systems. Springer, Berlin, 721 pp.

Diessel, C.F.K., 1998. Sequence stratigraphy applied to coal seams: two case histories. In: Shanley, K.W., McCabe, P.J. (Eds.), Relative Role of Eustasy, Climate and Tectonism in Continental Rocks. SEPM Special Publication 59, 151-173.

Du Toit, A.L., 1954. The Geology of South Africa. Oliver and Boyd, Edinburgh, 611 pp.

Falcon, R.M.S., 1975. Palynostratigraphy of the Lower Karroo sequence in the central Sebungwe District, Mid-Zambezi Basin, Rhodesia. Palaeontologia africana 18, 1-29.

Falcon, R.M.S., 1978. A palynological comparison of Karoo sediments on opposite sides of the Rhodesian Watershed with stratigraphic application. PhD Thesis, University of the Witwatersrand, Johannesburg, $480 \mathrm{pp}$.

Falcon, R.M.S., 1986. A brief review of the origin, formation and distribution of coal in Southern Africa. In: Anhaeusser, C.R. and Maske, S. (Eds.), Mineral deposits of Southern Africa. Geological Society of South Africa, Pretoria, pp. 1879-1898.

Falcon, R.M.S., Snyman, C.P., 1986. An Introduction to Coal Petrography: Atlas of Petrographic Constituents in the Bituminous Coals of Southern Africa. Review Paper Number 2, 27 pp. + 39 Plates, Geological Society of South Africa, Johannesburg. 
Falcon, R.M.S., Pinheiro, H.J., Sheperd, P., 1984. The palynobiostratigraphy of the major coal seams in the Witbank Basin with lithostratigraphic, chronostratigraphic and palaeoclimatic implications. Comunicações dos Serviços Geológicos Portugal 70, 215-243.

Faure, K., Cole, D., 1999. Geochemical evidence for lacustrine microbial blooms in the vast Permian Main Karoo, Paraná, Falkland Islands and Huab basins of southwestern Gondwana.

Palaeogeography, Palaeoclimatology, Palaeoecology 152, 189-213.

Fensome, R.A., Williams, G.L., Barss, M.S., Freeman, J.M., Hill, J.M., 1990. Acritarchs and fossil prasinophytes: an index to genera, species and intraspecific taxa. American Association of Stratigraphic Palynologists, Contributions Series 25, 1-771.

Fildani, A., Weislogel, A., Drinkwater, N., McHargue, T., Tankard, A., Wooden, J., Hodgson, D., Flint, S., 2009. U-Pb zircon ages from the southwestern Karoo Basin, South Africa: Implications for the Permian-Triassic boundary. Geology 37, 719-722.

Gastaldo, R.A., Demko, T.M., Liu, Y., 1993. Application of sequence and genetic stratigraphic concepts to carboniferous coal-bearing strata: an example from the Black Warrior Basin, USA. Geologische Rundschau 82, 212-226.

Gastaldo, R.A., Kamo, S.L., Neveling, J., Geissman, J.W., Bamford, M., Looy, C.V., 2015. Is the vertebrate-defined Permian-Triassic boundary in the Karoo Basin, South Africa, the terrestrial expression of the end-Permian marine event? Geology 43, 1-5.

Geel, C., Schulz, H-M., Booth, P., de Wit, M., Horsfield, B., 2013. Shale gas characteristics of Permian black shales in South Africa: results from recent drilling in the Ecca Group Eastern Cape. Energy Procedia 40, 256-265.

Geel, C., de Wit, M., Booth, P., Schulz, H.-M., Horsfield, B., 2015. Palaeo-environment, diagenesis and characteristics of Permian black shales in the Lower Karoo Supergroup flanking the Cape Fold Belt near Jansenville, eastern Cape, South Africa: Implications for the shale gas potential of the Karoo Basin. South African Journal of Geology 118(3), 249-274. 
Gorin, G.E., Feist-Burkhardt, S., 1990. Organic facies of Lower to Middle Jurassic sediments in the Jura Mountains, Switzerland. Review of Palaeobotany and Palynology 65, 349-355.

Götz, A.E., 2014. The Permian Whitehill Formation (Karoo Basin, South Africa): deciphering the complexity and potential of an unconventional gas resource. Geophysical Research Abstracts, Vol. 16: EGU2014-1399.

Götz, A.E., 2015. Palynological records of Gondwana's mid-Permian climate amelioration: New insights from black shale deposits (Collingham Formation, South Africa). Geophysical Research Abstracts, Vol. 17: EGU2015-2315.

Götz, A.E., Ruckwied, K., 2014. Palynological records of the Early Permian postglacial climate amelioration (Karoo Basin, South Africa). Palaeobiodiversity and Palaeoenvironments 94(2), 229235.

Götz, A.E., Wheeler, A., 2018. Challenges of Gondwanan marine-nonmarine correlations - a palynological perspective. Palaeontological Journal 52(1). [in press]

Götz, A.E., Ruckwied, K., Littke, R., Hartkopf-Fröder, C., 2012. Facies, sedimentary organic matter content and coal petrography of the No. 2 coal seam, northern Witbank Basin (South Africa). Proceedings of the 34th International Geological Congress 2012, Abstract 3383 (CD-ROM, ISBN 9780-646-57800-2), Brisbane.

Haldorsen, S., Von Brunn, V., Maud, R., Truter, E.D., 2001. A Weichselian deglaciation model applied to the Early Permian glaciation in the northeast Karoo Basin, South Africa. Journal of Quaternary Science 16(6), 583-593.

Hancox, P.J., Götz, A.E., 2014. South Africa's coalfields - a 2014 perspective. International Journal of Coal Geology 132, 170-254.

Haughton, S.H., Blignaut, J.J.G., Rossouw, P.J., Spies, J.J., Zagt, S., 1953. Results of an investigation into the possible presence of oil in Karroo rocks in parts of the Union of South Africa. Geological Survey of South Africa Memoir 54, 1-130. 
Hart, G.F., 1964. Where was the Lower Karroo Sea? Scientific South Africa 1, 289-290.

Hart, G.F., 1969. Lower Karroo (Permian) Acanthomorphitae Acritarchs from South Africa.

Palaeontologia Africana 12, 53-73.

Hart, G.F., 1970. Micropalaeontology of the Karroo deposits in South and Central Africa. In: IUGS Secretariat (Ed.), Reviews of the $1^{\text {st }}$ Symposium on Gondwana Stratigraphy 1967, Mar del Plata, pp. 161-172.

Hart, G.F., 1971. The Gondwana Permian Palynofloras. Anais da Academia Brasileira de Ciências 43, 145-185.

Henderson, C.M., Davydov, V.I., Wardlaw, B.R., 2012. The Permian Period. In: Gradstein, F.M., Ogg, J. G., Schmitz, M., Ogg, G. (Eds.), The Geologic Time Scale, Vol II. Elsevier, 653-679.

Herbert, C.T., Compton, J.S., 2007. Depositional environments of the lower Permian Dwyka diamictite and Prince Albert shale inferred from the geochemistry of early diagenetic concretions, southwest Karoo Basin, South Africa. Sedimentary Geology 194, 263-277.

Holz, M., 1998. The Early-Permian coal seams of the Paraná Basin in southernmost Brazil: an analysis of the depositional conditions using sequence stratigraphic concepts. International Journal of Coal Geology 36(1-2), 141-163.

Holz, M., 1999. Early Permian sequence stratigraphy and the palaeophysiographic evolution of the Paraná Basin in southernmost Brazil. Journal of African Earth Science 29(1), 51-61.

Holz, M., Kalkreuth, W., Banerjee, I., 2002. Sequence stratigraphy of paralic coal-bearing strata: an overview. International Journal of Coal Geology 48, 147-179.

Holz, M., Dias, M.E., 1998. Taphonomy of palynological records in a sequence stratigraphic framework: an example from the Early Permain Paraná Basin of southern Brazil. Review of Palaeobotany and Palynology 99, 217-233. 
Iannuzzi, R., Souza, P.A., Holz, M., 2010. Stratigraphic and palaeofloristic record of the Lower Permian postglacial succession in the southern Brazilian Paraná Basin. In: López-Gamundí, O.R., Buatois, L.A. (Eds.), Late Paleozoic Glacial Events and Postglacial Transgressions in Gondwana. GSA Special Paper 468, 113-132.

Johnson, M.R., 2009. Ecca Group. In: Johnson, M.R. (Ed.), Catalogue of South African lithostratigraphic units. South African Committee for Stratigraphy, Pretoria, pp. 5-7.

Johnson, M.R., Van Vuuren, C.J., Hegenberger, W.F., Key, R., Shoko, U., 1996. Stratigraphy of the Karoo Supergroup in southern Africa: an overview. Journal of African Earth Sciences 23(1), 3-15.

Johnson, M.R., van Vuuren, C.J., Visser, J.N.J., Cole, D.I., Wickens, H. de V., Christie, A.D.M., Roberts, D.L., 1997. The Foreland Karoo Basin, South Africa. In: Selley, R.C. (Ed.), Sedimentary Basins of the World: African Basins. Elsevier, Amsterdam, pp. 269-317.

Johnson, M.R., Van Vuuren, C.J., Visser, J.N.J., Cole, D.I.,Wickens, H., de, V., Christie, A.D.M., Roberts, D.L., Brandl, G., 2006. Sedimentary rocks of the Karoo Supergroup. In: Johnson, M.R., Anhaeusser, C.R., Thomas, R.J. (Eds.), The Geology of South Africa. Geological Society of South Africa, Johannesburg/Council for Geoscience, pp. 461-499.

Laurie, J.R., Bodorkos, S., Nicoll, R.S., Crowley, J.L., Mantle, D.J., Mory, A.J., Wood, G.R., Backhouse, J., Holmes, E.K., Smith, T.E., Champion, D.C., 2016. Calibrating the middle and late Permian palynostratigraphy of Australia to the geologic time-scale via U-Pb zircon CA-IDTIMS dating. Australian Journal of Earth Sciences 63(6), 701-730.

Lindeque, A., De Wit, M.J., Ryberg, T., Weber, M., Chevallier, L., 2011. Deep crustal profile across the southern Karoo Basin and Beattie Magnetic Anomaly, South Africa: An integrated interpretation with tectonic implications. South African Journal of Geology 114(3/4), 265-292.

Le Blanc Smith, G., 1980. Genetic stratigraphy and palaeoenvironmental controls on coal distribution in the Witbank Basin Coalfield. PhD Thesis, University of the Witwatersrand, Johannesburg, 242 pp. 
Leckie, D.A., Singh, C., Bloch, J., Wilson, M., Wall, J., 1992. An anoxic event at the AlbianCenomanian boundary: the Fish Scale Marker Bed, northern Alberta, Canada. Palaeogeography, Palaeoclimatology, Palaeoecology 92, 139-66.

Lei, Y., Servais, T., Feng, Q., 2013. The diversity of the Permian phytoplankton. Review of Palaeobotany and Palynology 198, 145-161.

Lindström, S., 1995. Early Permian palynostratigraphy of the northern Heimefrontfjella mountainrange, Dronning Maud Land, Antarctica. Review of Palaeobotany and Palynology 89, 359-415.

Lindström, S., 2005. Palynology of Permian shale, clay and sandstone clasts from the Basen till in northern Vestfjella, Dronning Maud Land. Antarctic Science 17(1), 87-96.

Lindström, S., McLoughlin, S., 2007. Synchronous palynofloristic extinction and recovery after the end-Permian event in the Prince Charles Mountains. Antarctica: implications for palynofloristic turnover across Gondwana. Review of Palaeobotany and Palynology 145, 89-122.

López-Gamundí, O.R., 2010. Transgressions related to the demise of the Late Paleozoic Ice Age: Their sequence stratigraphic context. In: López-Gamundí, O.R., Buatois, L.A. (Eds.), Late Paleozoic glacial events and postglacial transgressions in Gondwana. GSA Special Paper 468, 1-35.

Lüning, S., Craig, J., Loydell, D. K., Štorch, P., Fitches, B., 2000. Lower Silurian 'hot shales' in North Africa and Arabia: regional distribution and depositional model. Earth-Science Reviews 49(1-4), 121200.

MacRae, C.S., 1988. Palynostratigraphic correlation between the Lower Karoo sequence of the Waterberg and Pafuri coal-bearing basins and the Hammanskraal plant macrofossil locality, Republic of South Africa. Memoirs of the Geological Survey of South Africa 75, 1-217.

McKay, M.P., Weislogel, A.L., Fildani, A., Brunt, R.L., Hodgson, D.M., Flint, S.S., 2015. U-PB zircon tuff geochronology from the Karoo Basin, South Africa: implications of zircon recycling on stratigraphic age controls. International Geology Review 57, 393-410. 
McLachlan, I.R., Anderson, A.M., 1973. A review of the evidence for marine conditions in southern Africa during Dwyka times. Palaeontologia Africana 15, 37-64.

Metcalfe, I., Crowley, J.L., Nicoll, R.S., Schmitz, M., 2015. High-precision U-Pb CA-TIMS calibration of middle Permian to lower Triassic sequences, mass extinction and extreme climate-change in eastern Australian Gondwana. Gondwana Research 28(1), 61-81.

Milani, E.J., França, A.B., Schneider, R.L., 1994. Bacia do Paraná. Boletim de Geociências da Petrobras 8, 69-82.

Milani, E.J., Faccini, U.F., Scherer, C.M., Araújo, L.M., Cupertino, J.A., 1998. Sequences and stratigraphic hierarchy of the Paraná Basin (Ordovician to Cretaceous), southern Brazil. Boletim do Instituto de Geociências, Universidade de Sâo Paulo 29, 125-173.

Modesto, S.P., 2006. The cranial skeleton of the Early Permian aquatic reptile Mesosaurus tenuidens: implications for relationships and palaeobiology. Zoological Journal of the Linnean Society 146, 345368.

Montañez, I.P., Tabor, N.J., Niemeier, D., DiMichele, W.A., Frank, T.D., Fielding, C.R., Isbell, J.L., 2007. $\mathrm{CO}_{2}$-forced climate and vegetation instability during Late Paleozoic deglaciation. Science 315, 87-91.

Mowzer, Z., Adams, S., 2015. Shale gas prospectivity analysis of the southern Main Karoo Basin. Petroleum Agency South Africa contribution to the strategic environmental assessment, Agency report FG 2015, 1-57.

Nicoll, R., McKellar, J., Ayaz, S.A., Laurie, J.R., Esterle, J., Crowley, J., Wood, G., Bodorkos, S., 2015. CA-IDTIMS dating of tuffs, calibration of palynostratigraphy and stratigraphy of the Bowen and Galilee basins. In: Bowen Basin Symposium, 211-218.

Oelofsen, B.W., 1981. An anatomical and systematic study of the family Mesosauridae (Reptilia: Proganosauria) with special reference to its associated fauna and palaeoecological environment in the Whitehill Sea. PhD Thesis, Stellenbosch University, Stellenbosch, 163 pp. 
Oelofsen, B.W., 1987. The biostratigraphy and fossils of the Whitehill and Irati Shale Formations of the Karoo and Paraná Basins. In: McKenzie, G.D. (Ed.), Gondwana Six: Stratigraphy, Sedimentology, and Paleontology. Geophysical Monograph Series, American Geophysical Union 41, 131-138.

Oelofsen, B., Araújo, D.C., 1983. Palaeoecological implications of the distribution of mesosaurid reptiles in the Permian Irati Sea (Paraná Basin), South America. Revista Brasileira de Geociências 13(1), 1-6.

Piñeiro, G., Ramos, A., Goso, C., Scarabino, F., Laurin, M., 2012. Unusual environmental conditions preserve a Permian mesosaur-bearing Konservat-Lagerstätte from Uruguay. Acta Palaaeontologica Polonica 57(2), 299-318.

Prauss, M., Ligouis, B., Luterbacher, H., 1991. Organic matter and palynomorphs in the 'Posidonienschiefer' (Toarcian, Lower Jurassic) of southern Germany. In: Tyson, R.V., Pearson, T.H. (Eds.), Modern and Ancient Continental Shelf Anoxia. Geological Society Special Publication 58, 335351.

Price, P.L., 1997. Permian to Jurassic palynostratigraphic nomenclature of the Bowen and Surat basins. In: Green, P. (Ed.), The Surat and Bowen Basins, Southeast Queensland. Queensland Department of Mines and Energy, Brisbane, 137-178.

Retallack, G.J., 2011. Exceptional fossil preservation during $\mathrm{CO}_{2}$ greenhouse crises? Palaeogeography, Palaeoclimatology, Palaeoecology 307, 59-74.

Retallack, G.J., 2013. Permian and Triassic greenhouse crises. Gondwana Research 24, 90-103. Rilett, M.H.P., 1963. A fossil cephalopod from Middle Ecca beds in the Klip River coalfield near Dundee, Natal. Transactions of the Royal Society of South Africa 37, 73-74.

Rubidge, B.S., Erwin, D.H., Ramezani, J., Bowring, S.A., De Klerk, W.J., 2013. High-precision temporal calibration of late Permian vertebrate biostratigraphy: U-Pb constraints from the Karoo Supergroup, South Africa. Geology 41(3), 363-366. 
Ruckwied, K., Götz, A.E., Jones, P., 2014. Palynological records of the Permian Ecca Group (South Africa): Utilizing climatic icehouse-greenhouse signals for cross basin correlations. Palaeogeography, Palaeoclimatology, Palaeoecology 413, 167-172.

Ryan, P.J., 1968. Some conclusions drawn from a basinal analysis of the Ecca Series in the Karroo Basin. Palaeontologia Africana 11, 133-134.

Rowsell, D.M., de Swardt, A.M.J., 1976. Diagenesis in Cape and Karoo sediments, South Africa, and its bearing on their hydrocarbon potential. Transactions of the Geological Society of South Africa 79, 81-145.

Scheffler, K., Buehmann, D., Schwark, L., 2006. Analysis of late Palaeozoic glacial to postglacial sedimentary successions in South Africa by geochemical proxies - Response to climate evolution and sedimentary environment. Palaeogeography, Palaeoclimatology, Palaeoecology 240, 184-203.

Schneider, J.W., Shen, S., Richards, B.C., Lucas, S.G., Barrick, J., Werneburg, R., Wang, X., Kerp, H., Nurgaliev, D.K., Davydov, V., Golubev, V., Urazaeva, M.N., Rößler, R., Voigt, S., Saber, H., Götz, A.E., Ronchi, A., Oplustil, S., Scholze, F., Abouchouaib, B., 2014. Report on the activities of the NonmarineMarine Correlation Working Group for 2014 - program for 2015 and future tasks. Permophiles 60, $31-36$.

Schulz, H.-M., Chere, N., Geel, C., Booth, P., de Wit, M.J., 2016. Is the postglacial history of the Baltic Sea an appropriate analogue for the formation of black shales in the Lower Ecca Group (Early Permian) of the Karoo Basin, South Africa? In: Linol, B., de Wit, M.J. (Eds.), Origin and Evolution of the Cape Mountains and Karoo Basin. Regional Geology Reviews, Springer, pp. 111-117.

Scotese, C., 2016. A new global temperature curve for the Phanerozoic. Geological Society of America, Abstracts with Programs 48(7), Paper No. 74-31; doi: 10.1130/abs/2016AM-287167.

Shen, S.-Z., Schneider, J.W., Angiolini, L., Henderson, C.M., 2013. The International Permian Timescale: March 2013 update. In: Lucas, S.G., DiMichele, W., Barrick, J.E., Schneider, J.W., Spielmann, J.A., (Eds.), The Carboniferous-Permian Transition. New Mexico Museum of Natural History and Science, Bulletin 60, 411-416. 
Silva, R.R., Ferigolo, J., Bajdek, P., Piñeiro, G., 2017. The Feeding Habits of Mesosauridae. Frontiers in Earth Science 5, 23.

Smith, R.M.H., Eriksson, P.G., Botha, W.J., 1993. A review of the stratigraphy and sedimentary environments of the Karoo-aged basins of Southern Africa. Journal of African Earth Sciences 16, 143169.

Smithard, T., Bordy, E.M., Reid, D., 2015. The effect of dolerite intrusions on the hydrocarbon potential of the Lower Permian Whitehill Formation (Karoo Supergroup) in South Africa and southern Namibia: a preliminary study. South African Journal of Geology 118(4), 489-510.

Snyman, C.P., 1998. Coal. In: Wilson, M.G.C., Anhaeusser, C.R (Ed.), The Mineral Resources of South Africa. Council for Geoscience Handbook 16, pp. 136-205.

Stanistreet, I.G., Le Blanc Smith, G., Cadle, A.B., 1980. Trace fossils as sedimentological and palaeoenvironmental indices in the Ecca group (Lower Permian) of the Transvaal. Transactions of the Geological Society of South Africa 83, 333-344.

Stavrakis, N., 1986. Sedimentary environments and facies of the Orange Free State Coalfields. In: Anhaeusser, C.R., Maske, S. (Eds.), Mineral Deposits of Southern Africa, Vol. II. Geological Society of South Africa, Pretoria, pp. 1939-1952.

Sternbeck, J., Sohlenius, G., 1997. Authigenic sulfide and carbonate mineral formation in Holocene sediments of the Baltic Sea. Chemical Geology 135(1-2), 55-73.

Steyn, P.P.A., Van der Linde, P.J., 1986. Vereeniging-Sasolburg Coalfield. In: Anhaeusser, C.R., Maske, S. (Eds.), Mineral Deposits of Southern Africa, Vol. II. Geological Society of South Africa, Pretoria, pp. $1923-1927$.

Stollhofen, H., Stanistreet, I.G., Bangert, B., Grill, H., 2000. Tuffs, tectonism and glacially related sealevel changes, Carboniferous-Permian, southern Namibia. Palaeogeography, Palaeoclimatology, Palaeoecology 161, 127-150. 
Strother, P.K., 1996. Acritarchs. In: Jansonius, J., McGregor, D.C. (Eds.), Palynology: principles and applications. American Association of Stratigraphic Palynologists Foundation 1, 81-106.

Souza, P.A., Marques-Toigo, M., 2005. Progress on the palynostratigraphy of the Permian strata in Rio Grande do Sul State, Paraná Basin, Brazil. Anais da Academia Brasileira de Ciências 77(2), 353365.

Sun, Y., Joachimski, M.M., Wignall, P.B., Yan, C., Chen, Y., Jiang, H., Wang, L., Lai, X., 2012. Lethally hot temperatures during the early Triassic greenhouse. Science 338, 366-370.

Tankard, A., Welsink, H., Aukes, P., Newton, R., Stettler, E., 2009. Tectonic evolution of the Cape and Karoo basins of South Africa. Marine and Petroleum Geology 26(8), 1379-1412.

Teichert, C., Rilett, M., 1974. Revision of Permian Ecca Series cephalopods, Natal, South Africa. University of Kansas Paleontological Contributions 74, 1-8.

Traverse, A., 2007. Paleopalynology. 2nd Edition, Springer, Berlin, 816 pp.

Tyson, R.V., 1987. The genesis and palynofacies characteristics of marine petroleum source rocks. In: Brooks, J., Fleet, A.J. (Eds.), Marine Petroleum Source Rocks. Geological Society Special Publication $26,47-67$.

Tyson, R.V., 1989. Late Jurassic palynofacies trends, Piper and Kimmeridge Clay Formations, UK onshore and offshore. In: Batten, D.J., Keen, M.C. (Eds.), Northwest European Micropalaeontology and Palynology. British Micropalaeontological Society Series, Ellis Horwood, Chichester, pp. 135-172.

Tyson, R.V., 1993. Palynofacies analysis. In: Jenkins, D.G. (Ed.), Applied Micropaleontology. Kluwer Academic Publishers, Dordrecht, pp. 153-191.

Tyson, R.V., 1995. Sedimentary Organic Matter: Organic Facies and Palynofacies. Chapman \& Hall, London, $615 \mathrm{pp}$.

Van Vuuren, C.J., 1981. Depositional models for the Vryheid Formation in the northeastern part of the Karoo Basin - a review. Annals of the Geological Survey of South Africa 15, 1-11. 
Van Vuuren, C.J., 1983. A basin analysis of the northern facies of the Ecca Group. PhD Thesis, University of the Orange Free State, Bloemfontein, 249 pp.

Veevers, J.J., Cole, D.I., Cowan, E.J., 1994. Southern Africa: Karoo Basin and Cape Fold Belt. In: Veevers, J.J., Powell, C.McA. (Eds.), Permian-Triassic Pangean Basins and fold belts along the Panthalassan Margin of Gondwanaland. GSA Memoir 184, 223-279.

Venter, M.E., Cairncross, B., 1995. Acritarchs from the Number 5 Seam in the Permian Vryheid Formation, Witbank Coalfield, South Africa. South African Journal of Geology 98(4), 479-487.

Viljoen, J.H.A., 1992. Lithostratigraphy of the Collingham Formation (Ecca Group), including the Zoute Kloof, Buffels River and Wilgehout River Members and the Matjiesfontein Chert Bed. South African Committee for Stratigraphy, Lithostratigraphic Series 22, 10 pp.

Visser, J.N.J., 1987. The palaeogeography of part of southwestern Gondwana during the PermoCarboniferous glaciation. Palaeogeography, Palaeoclimatology, Palaeoecology 61, 205-219.

Visser, J.N.J., 1989. The Permo-Carboniferous Dwyka Formation of Southern Africa: deposition by a predominantly subpolar marine ice sheet. Palaeogeography, Palaeoclimatology, Palaeoecology 70, 377-391.

Visser, J.N.J., 1992. Deposition of the Early to Late Permian Whitehill Formation during a sea-level highstand in a juvenile foreland basin. South African Journal of Geology 95(5-6), 181-193.

Visser, J.N.J., 1993. Sea level changes in a back-arc-foreland transition: the late CarboniferousPermian Karoo Basin of South Africa. Sedimentary Geology 83(1-2), 115-131.

Visser, J.N.J., 1994. A Permian argillaceous syn- to post-glacial foreland sequence in the Karoo Basin, South Africa. In: Deynoux, M. et al. (Eds.), Earth's Glacial Record. Cambridge University Press, Cambridge, pp. 193-203. 
Visser, J.N.J., 1995. Post-glacial Permian stratigraphy and geography of southern and central Africa: boundary conditions for climatic modelling. Palaeogeography, Palaeoclimatology, Palaeoecology $118,213-243$.

Visser, J.N.J., Young, G.M., 1990. Major element geochemistry and paleoclimatology of the PermoCarboniferous glacigene Dwyka Formation and post-glacial mudrocks in southern Africa.

Palaeogeography, Palaeoclimatology, Palaeoecology 81, 49-57.

Wheeler, A., Götz, A.E., 2016. Palynofacies patterns of the Highveld coal deposits (Karoo Basin, South Africa): Clues to reconstruction of palaeoenvironment and palaeoclimate. Acta Palaeobotanica 56(1), 3-15.

Wheeler, A., Götz, A.E., 2017. Palynofacies as a tool for high-resolution palaeoenvironmental and palaeoclimatic reconstruction of Gondwanan post-glacial coal deposits: No. 2 Coal Seam, Witbank Coalfield (South Africa). Palaeobiodiversity and Palaeoenvironments 97(2), 259-271.

Wignall, P.B., 1994. Black shales. Oxford University Press, Oxford, 127 pp.

Winter, M.F.W., 1985. Lower Permian palaeoenvironments of the northern Highveld Coalfield and their relationship to the characteristics of coal seams. PhD Thesis, University of the Witwatersrand, Johannesburg, $254 \mathrm{pp}$.

Winter, M.F., Cairncross, B., Cadle, A.B., 1987. A genetic stratigraphy for the Vryheid Formation in the northern Highveld coalfield, South Africa. South African Journal of Geology 90, 333-343. 


\section{Figure Captions}

Fig. 1. Karoo Basin and location of studied boreholes (KZF-1, KWV-1, DP 1/78) and outcrops (Ecca Pass, Witbank and Highveld coalfields) of Permian black shales and coal deposits (map modified from Catuneanu et al., 1998). GPS coordinates of studied boreholes and outcrops: Borehole ALBN11

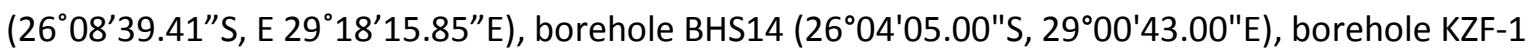
( $\left.32^{\circ} 50^{\prime} 30.43^{\prime \prime} \mathrm{S}, 19^{\circ} 44^{\prime} 33.02^{\prime \prime} \mathrm{E}\right)$, borehole KWV-1 (32 $\left.14^{\prime} 43.10^{\prime \prime} \mathrm{S}, 28^{\circ} 35^{\prime} 08.10^{\prime \prime} \mathrm{E}\right)$, borehole DP 1/78 $\left(29^{\circ} 23^{\prime} 60.00^{\prime \prime} \mathrm{S}, 24^{\circ} 26^{\prime} 24.00^{\prime \prime} \mathrm{E}\right)$, Ecca Pass $\left(33^{\circ} 12^{\prime} 58.60^{\prime \prime} \mathrm{S}, 26^{\circ} 37^{\prime} 38.30^{\prime \prime} \mathrm{E}\right)$. Lithostratigraphic units of the Karoo Supergroup (Dwyka, Ecca, Beaufort, Stormberg, and Drakensberg groups, Prince Albert and Whitehill formations) according to Johnson et al. $(1997,2006)$. Abbreviations used: Guad. = Guadalupian, Lop. = Lopingian (Shen et al., 2013).

Fig. 2. Glauconitic sandstone, a marker horizon above the No. 5 seam in the Witbank and Highveld coalfields, indicating a major transgressive event across the Karoo Basin. Vanggatfontein Exploration Project, borehole VG15-05A. Photo by courtesy of J.P. Hancox with permission of Keaton Energy Holdings.

Fig. 3. Palynofacies of the No. 5 coal seam, Witbank Coalfield (boreholes BHS14, ALBN11). All categories sum to $100 \%$ (scale $20 \%$ ). Percentages refer to total counts of 500 particles per slide. Depositional environments are distinguished by changes in the composition of phytoclast and palynomorph assemblages. Deltaic-marine conditions in the uppermost part of the seam are inferred from marine phytoplankton occurrence. Abbreviations used: AOM - amorphous organic matter, DOP - degraded organic particles.

Fig. 4. Palynofacies of the Prince Albert and Whitehill formations (a) and Collingham and Tierberg formations (b) illustrated in the AOM-Phytoclast-Palynomorph plot (Tyson, 1989, 1993, 1995). Data of borehole DP 1/78 from Ruckwied et al. (2014), Ecca Pass data from Götz (2015). (a) Prince Albert Formation data plotted as triangles and rectangles, Whitehill Formation data plotted as circles and diamond symbol; (b) Collingham Formation data plotted as diamond symbol, Tierberg Formation data as cross symbol. Facies field II represents marginal, dysoxic-anoxic depositional environments, facies field III proximal shelf, facies field IV shelf to basin transition with dysoxic-suboxic (IVa), and suboxic-anoxic (IVb) conditions, respectively. Facies field VII represents distal suboxic-anoxic basinal settings. Insert shows general proximal-distal and oxic-anoxic trends inferred from palynofacies data. A clear N-S deepening trend of the basin is documented during the deposition of the Prince Albert 
and Whitehill formations, the Prince Albert shale data indicating slightly shallower depositional conditions (fields II and IVa) in comparison to the Whitehill shale data (fields II, IVa/b, and VII). Collingham shale data (b) from the southern basin parts reveal a prominent shallowing upward trend with data plotting from field IVb to field IVa and field III upsection. Tierberg shale data from the northern basin plot in field III, indicating a proximal shelf setting.

Fig. 5. Marine phytoplankton peaks mark a basin-wide transgression during the deposition of the Whitehill shales with acritarch occurrence above coal seam No. 5 in the Witbank Coalfield. This event ("Whitehill event") is used for marine-nonmarine correlation and is interpreted to reflect the early Guadalupian (Roadian) initial transgression (Henderson et al., 2012) in the Karoo Basin. The percentages of marine phytoplankton are of the total sedimentary organic matter counts.

Fig. 6. Cross-basin correlation of marine black shales and fluvio-deltaic coal deposits based on palynology. Maximum flooding surfaces highlighted by dashed lines on top of coal seams. A major flooding event is detected within the Whitehill Formation ("Whitehill event"). Radiometric ages for the base of the Prince Albert Formation (marked by star, $288 \pm 3 \mathrm{Ma}$ ) from Bangert et al. (1999), and base Collingham Formation (marked by star, $268 \pm 3.2 \mathrm{Ma}$ ) from McKay et al. (2015), corresponding to a base Collingham age of $270 \pm 1$ Ma published by Stollhofen et al. (2000) from Namibia. Permian timescale from Shen et al. (2013).

Fig. 7. Facies distribution and boundaries of marine black shales and fluvio-deltaic coals of the Karoo Basin based on data compiled from Hart (1964, 1971), Van Vuuren (1983), Visser (1992, 1993), Johnson et al. (2006), Ruckwied et al. (2014), Chukwuma and Bordy (2016), and this study.

Fig. 8. Conceptual facies model of the Karoo Basin within the Panthalassan margin of Gondwana based on palynofacies. 
Tab. 1. Alphabetical list of identified palynomorph taxa, arranged under probable botanical affinities according to Balme (1995), Lindström (1995, 2005), and Lindström and McLoughlin (2007). Note: *commonly reported from the Main Karoo Basin as Alisporites ovatus (Balme \& Hennelly) Jansonius 1962.

\section{Botanical affinity}

Arthrophyta

Lycophyta

Pterophyta

\section{Taxa}

Calamospora spp.

Lundbladispora braziliensis (Pant \& Srivastava) Marques-Toigo \& Pons emend. Marques-Toigo \& Picarelli 1984

Apiculatisporis levis (Balme \& Hennelly) Segroves 1970

Apiculatisporis spp.

Cyclogranisporites sp.

Deltoidospora spp.

Granulatisporites sp.

Horriditriletes ramosus (Balme \& Hennelly) Bharadwaj \& Salujha

1964

Horriditriletes spp.

Laevigatosporites spp.

Leiotriletes spp.

Lophotriletes spp.

Microbaculispora spp.

Punctatisporites spp.

Verrucosisporites andersonii (Anderson) Backhouse 1988

Verrucosisporites spp.

Gymnosperms

Monocolpate grains

Praecolpate grains

Monosaccate grains

Non-taeniate bisaccate grains

Alisporites splendens (Leschik) Foster 1979

Alisporites spp.

Limitisporites sp.

Platysaccus papilionis Potonié \& Klaus 1954

Platysaccus sp.

Scheuringipollenites ovatus (Balme and Hennelly) Foster 1975*

Sulcatisporites spp.

Guttulapollenites hannonicus Goubin 1965

Lueckisporites virkkiae Potonié \& Klaus 1954 


\begin{tabular}{|c|c|}
\hline & Lunatisporites spp. \\
\hline & Protohaploxypinus limpidus (Balme \& Hennelly) Balme \& Playford \\
\hline & 1967 \\
\hline & Protohaploxypinus spp. \\
\hline & Striatoabieites multistriatus (Balme and Hennelly) Hart 1964 \\
\hline & Striatoabieites spp. \\
\hline & Striatopodocarpites cancellatus (Balme \& Hennelly) Hart 1963 \\
\hline & Striatopodocarpites fusus (Balme \& Hennelly) Potonié 1958 \\
\hline Costate grains & Vittatina costabilis Wilson 1962 \\
\hline & Vittatina fasciolata (Balme \& Hennelly) Bharadwaj 1962 \\
\hline & Vittatina subsaccata Samoilovich 1953 \\
\hline & Vittatina spp. \\
\hline & Weylandites lucifer (Bharadwaj \& Salujha) Foster 1975 \\
\hline Freshwater algae & Botryococcus sp. \\
\hline & Tetraporina sp. \\
\hline Marine phytoplan & \\
\hline Acritarchs & Micrhystridium spp. \\
\hline Prasinophytes & Cymatiosphaera gondwanensis (Tiwari) Backhouse 1991 \\
\hline & Cymatiosphaera sp. \\
\hline & Tasmanites sp. \\
\hline Leiospheres & Leiosphaeridia spp. \\
\hline
\end{tabular}

Tab. 2. Present-day TOC content of Permian black shales of the Prince Albert, Whitehill and Collingham formations (KZF-1 borehole, south-western Karoo Basin).

\begin{tabular}{lll}
\hline Sample depth (mbs) & Formation & TOC (wt.\%) \\
\hline 340.39 & Collingham & 1.7 \\
\hline 371.11 & Collingham & 1.0 \\
\hline 376.82 & Collingham & 0.9 \\
\hline 386.28 & Collingham & 1.3 \\
\hline 398.55 & Collingham & 2.2 \\
\hline 410.14 & Collingham & 1.7 \\
\hline 421.77 & Whitehill & 5.4 \\
\hline 457.30 & Whitehill & 5.7 \\
\hline 461.12 & Whitehill & 6.1 \\
\hline 514.30 & Prince Albert & 0.3 \\
\hline 539.92 & Prince Albert & 0.3 \\
\hline 561.96 & Prince Albert & 0.8 \\
\hline 590.34 & Prince Albert & 1.0 \\
\hline 612.90 & Prince Albert & 1.8 \\
\hline
\end{tabular}




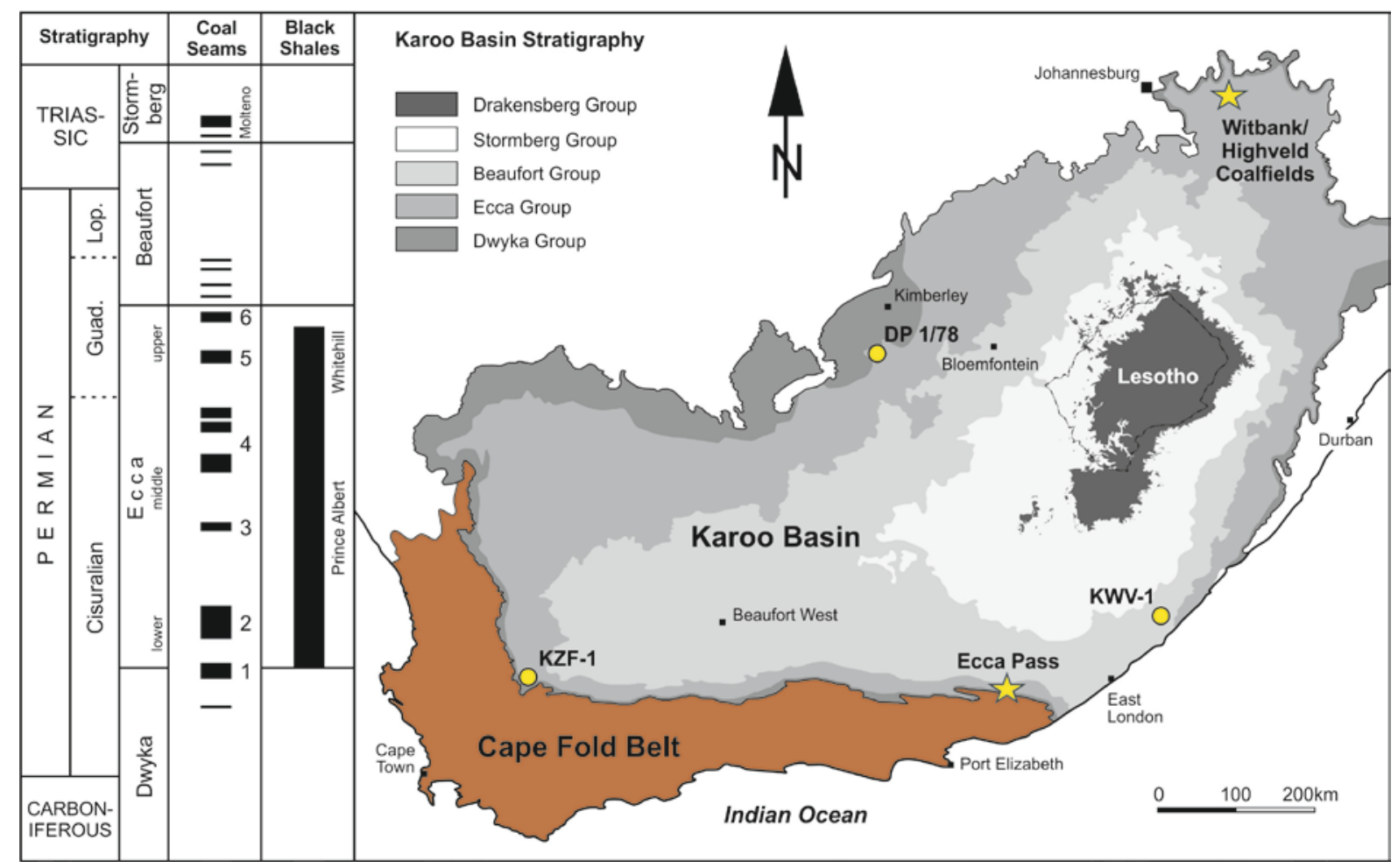

Figure 1

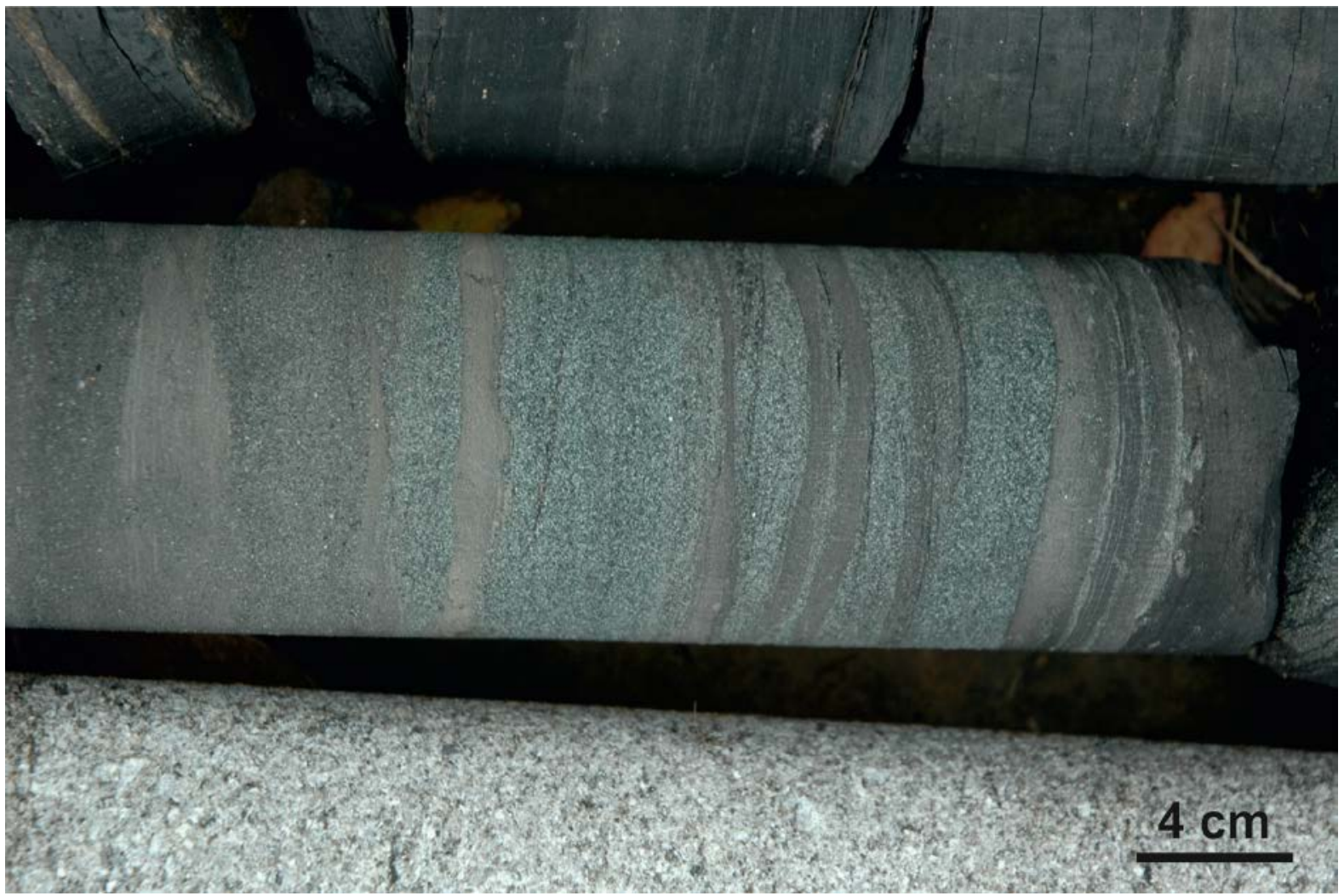

Figure 2 


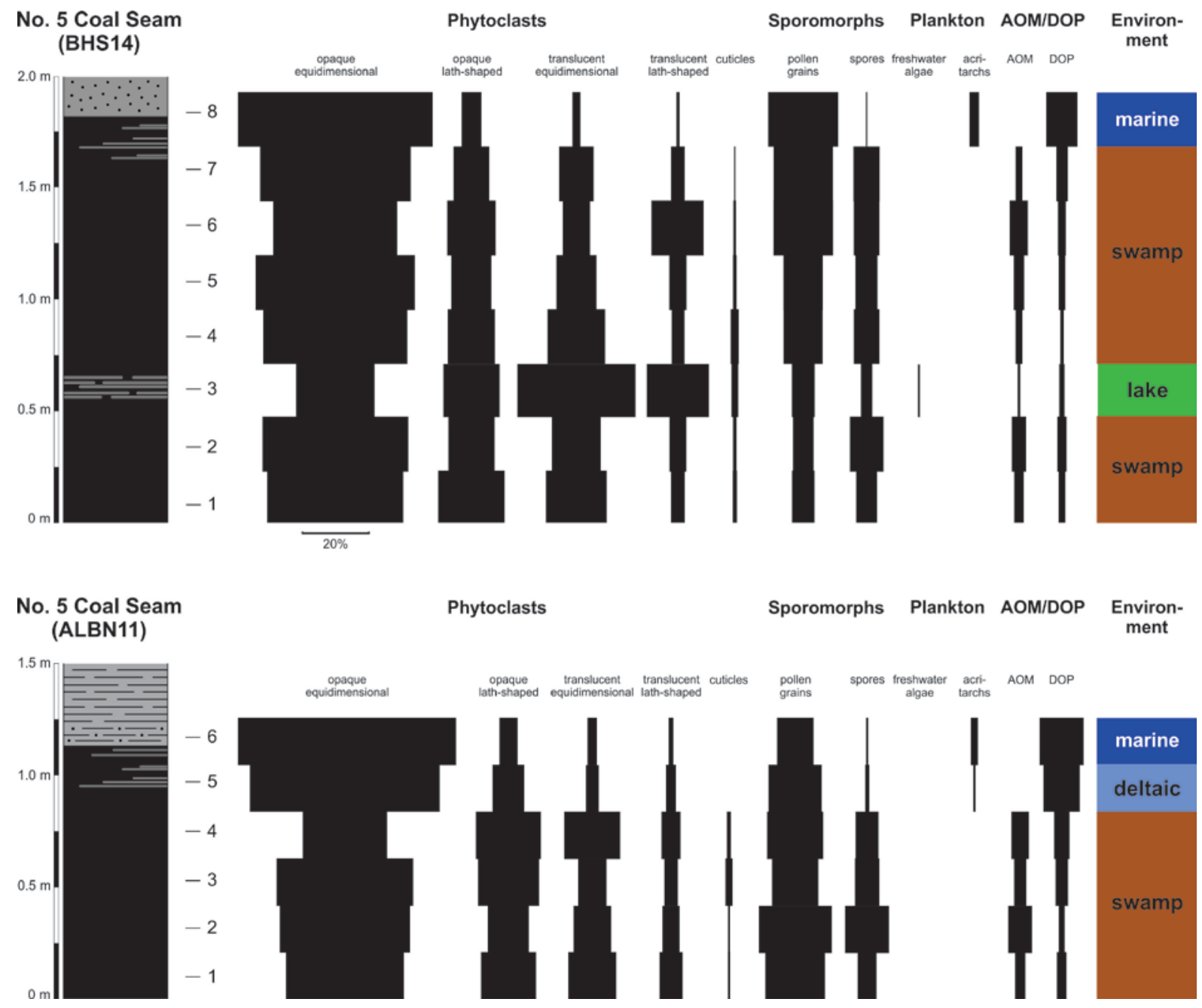

Figure 3
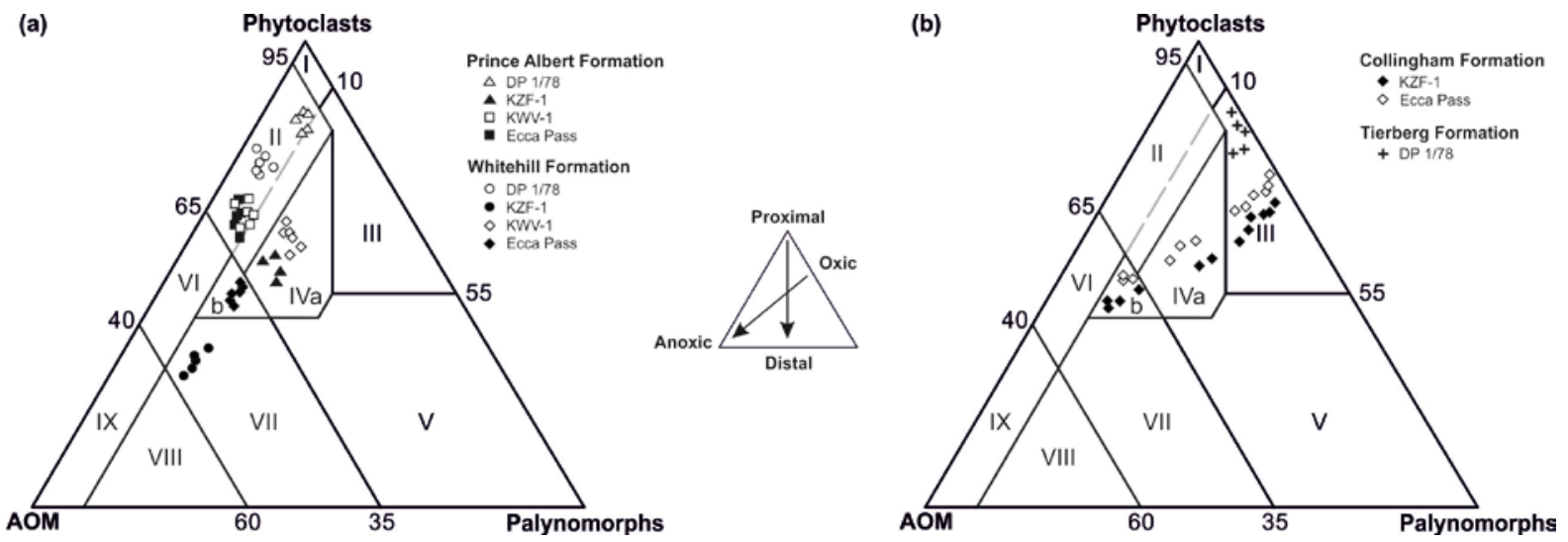

Figure 4 


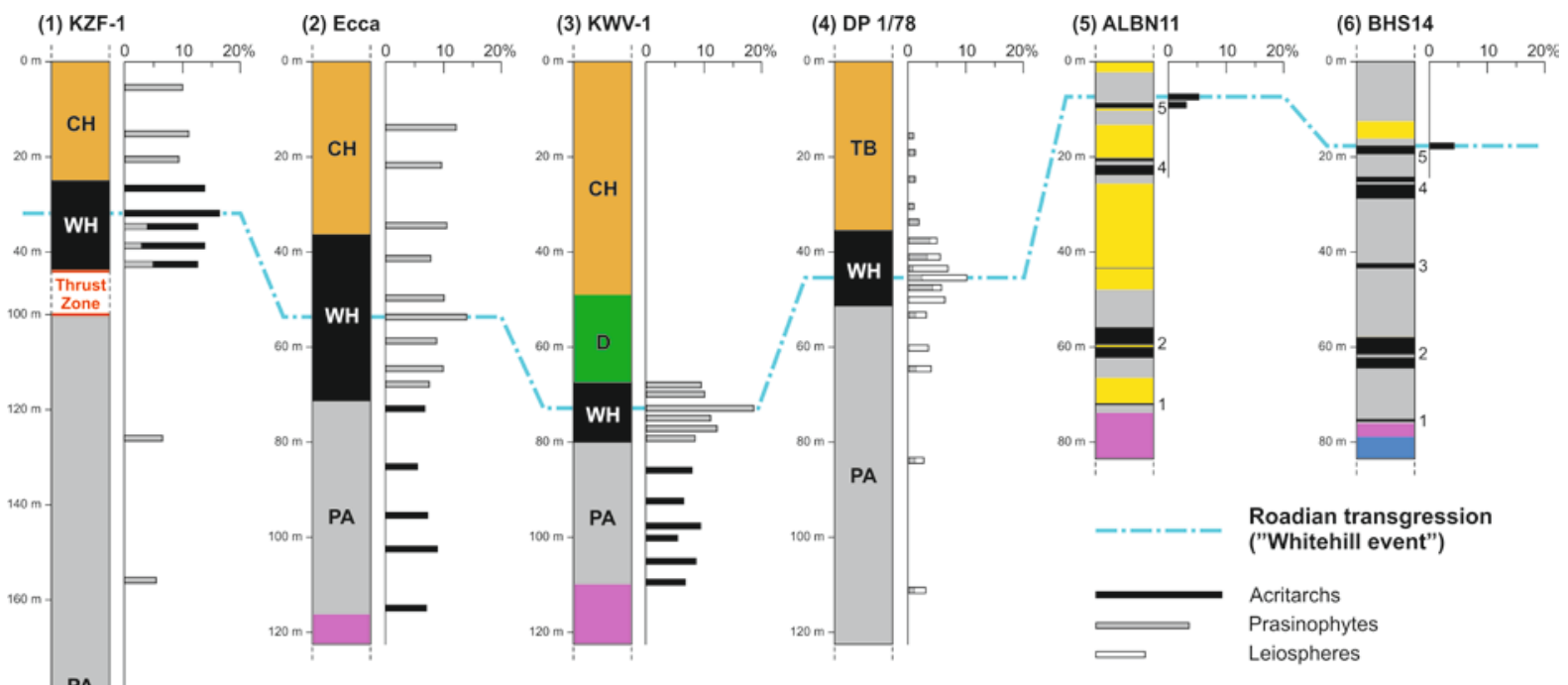

SW-SE-NW Karoo Basin (1-4)

NE Karoo Basin (5-6)

D Dolerite (Karoo LIP)

Sandstone

$\mathrm{CH} / \mathrm{TB}$ Collingham/Tierberg Fm. (Ecca Group)

WH Whitehill Fm. (Ecca Group)

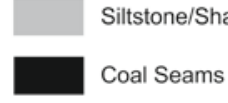

PA Prince Albert Fm. (Ecca Group)

Tillite (Dwyka Group)

Basement

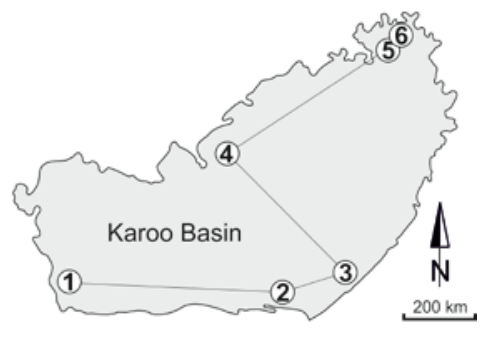

Figure 5

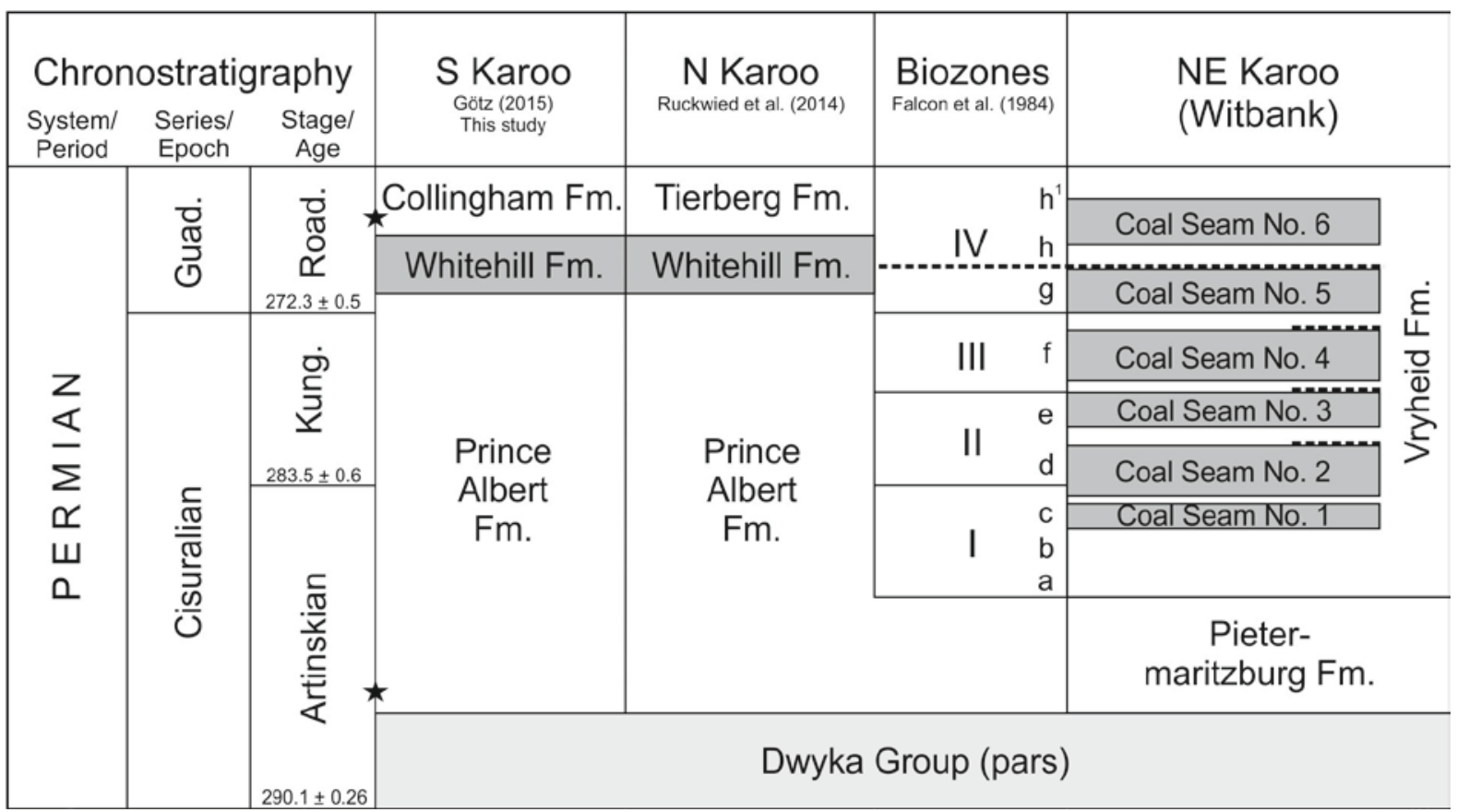

Figure 6 


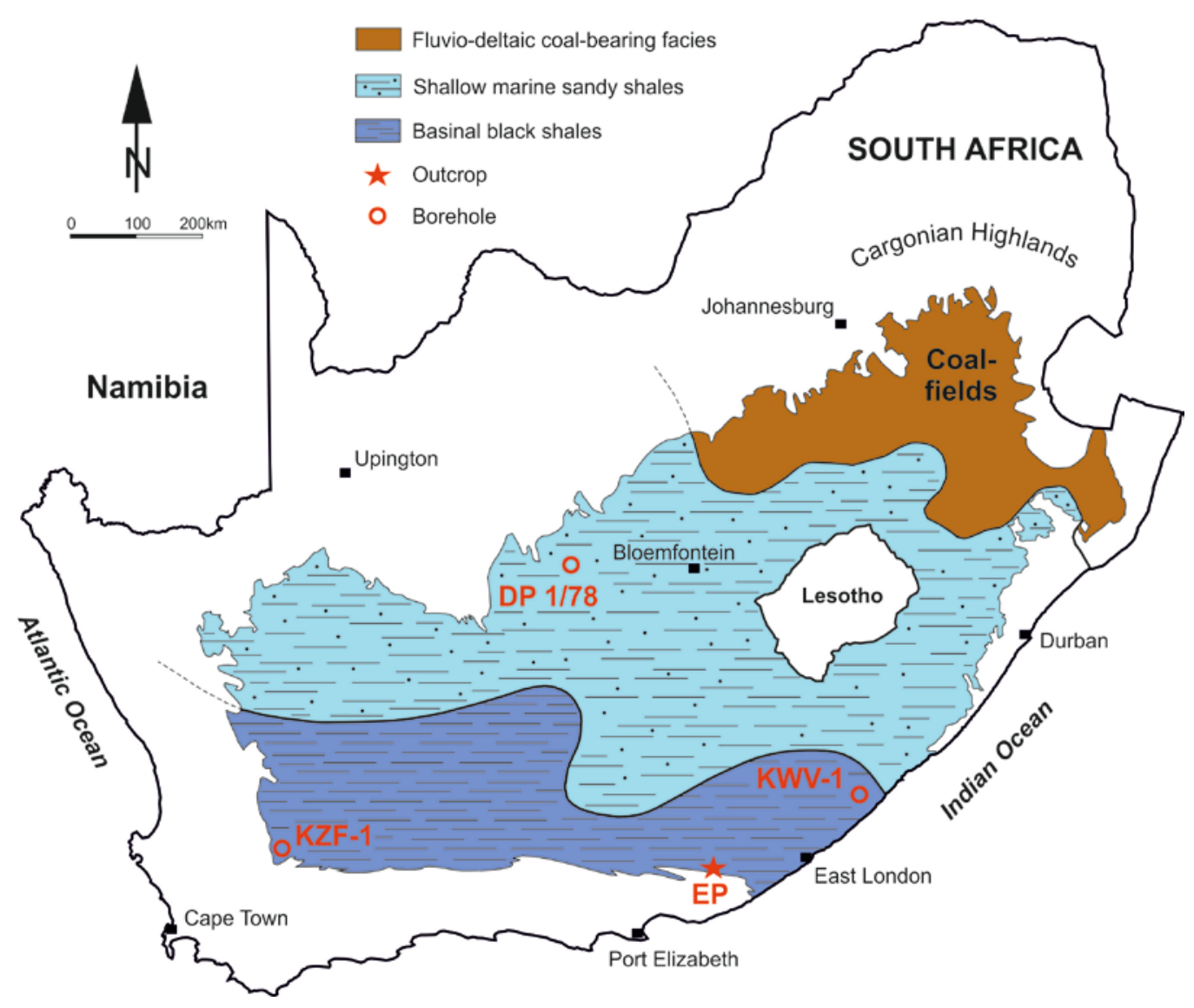

Figure 7

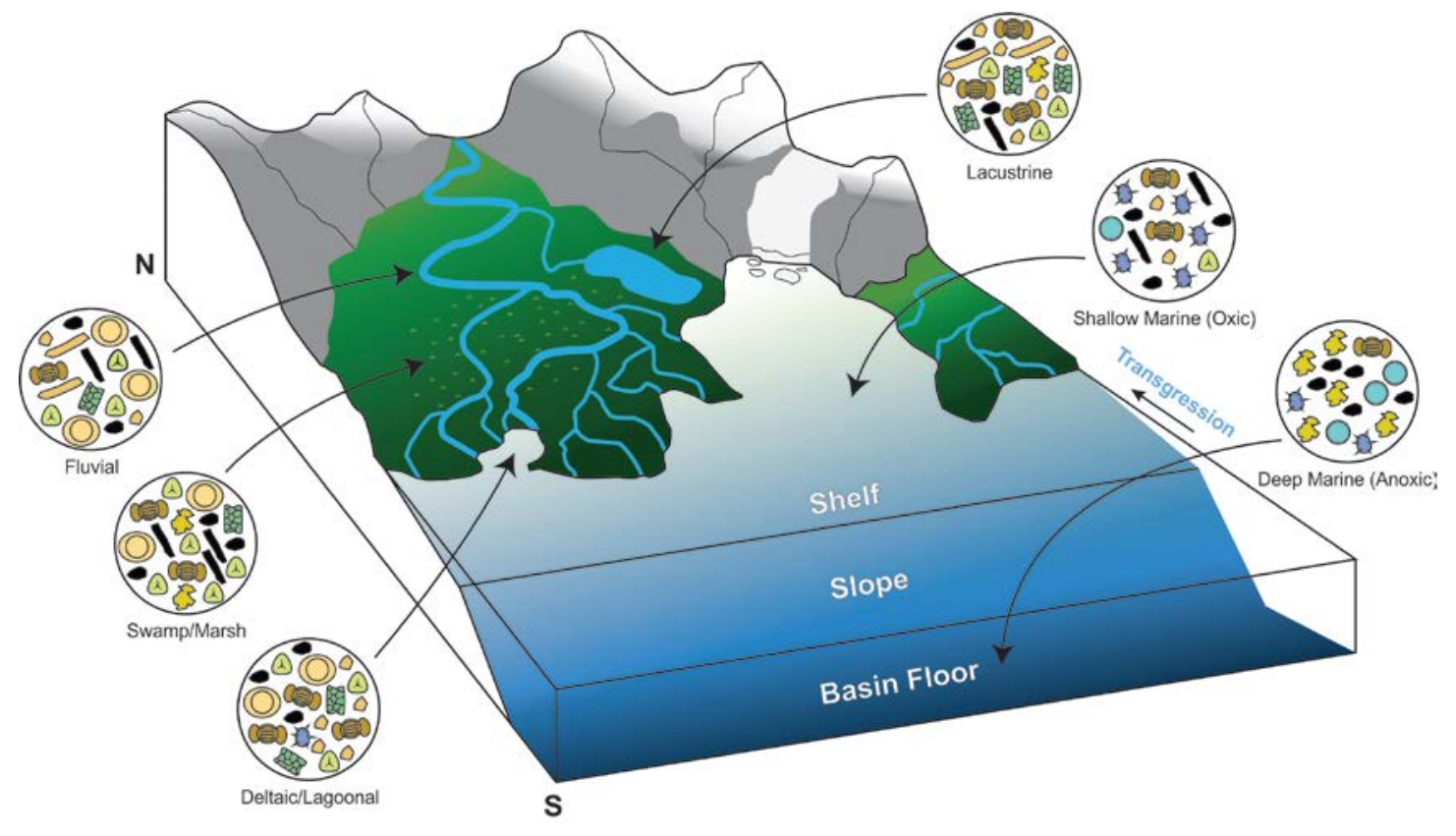

Legend

Figure 8 